\title{
Romania: First Review Under the Stand-By Arrangement, Request for Waiver of Nonobservance of Performance Criterion, and Request for Modification and Establishment of Performance Criteria; Statement by the IMF Staff Representative; and Press Release on the Executive Board Discussion;
}

The following documents have been released and are included in this package:

- $\quad$ The staff report, prepared by a staff team of the IMF, following discussions that ended on August 10, 2009, with the officials of Romania on economic developments and policies. Based on information available at the time of these discussions, the staff report was completed on September 10, 2009. The views expressed in the staff report are those of the staff team and do not necessarily reflect the views of the Executive Board of the IMF.

- $\quad$ A statement by the IMF staff representative.

- $\quad$ A Press Release on the Executive Board Discussion.

The document(s) listed below will be separately released.

Letter of Intent sent to the IMF by the authorities of Romania*

Technical Memorandum of Understanding*

*Also included in Staff Report

The policy of publication of staff reports and other documents allows for the deletion of market-sensitive information.

Copies of this report are available to the public from

International Monetary Fund $\bullet$ Publication Services

$70019^{\text {th }}$ Street, N.W. • Washington, D.C. 20431

Telephone: (202) 623-7430 • Telefax: (202) 623-7201

E-mail: publications@imf.org Internet: http://www.imf.org

\section{International Monetary Fund Washington, D.C.}


INTERNATIONAL MONETARY FUND

ROMANIA

\begin{abstract}
First Review Under the Stand-By Arrangement, Request for Waiver of Nonobservance of Performance Criterion, and Request for Modification and Establishment of Performance Criteria
\end{abstract}

Prepared by the European Department

(In Consultation with Other Departments)

Approved by Poul M. Thomsen and Aasim Husain

September 10, 2009

- $\quad$ Stand-By Arrangement: A 24 month, SDR 11.443 billion ( $€ 12.95$ billion, US\$17.07 billion, 1,110.77 percent of quota) Stand-By Arrangement was approved by the Executive Board on May 4, 2009 (Country Report No.09/183), and a first purchase of SDR 4.37 billion was made following the Board meeting. The second tranche, subject to the completion of this (first) review, amounts to SDR 1.718 billion. The European Commission and the World Bank are also providing funds to cover the financing gap under the program.

- Program status: All end-June 2009 quantitative performance criteria and indicative targets have been met, with the exception of the ceiling on general government domestic arrears, for which a waiver is requested (supported by staff on the basis of corrective action being taken). End-June inflation was well within the inner target band. The end-August structural benchmark on parliamentary approval of fiscal adjustment measures has been met in April significantly ahead of schedule, and the structural benchmarks on revising banking and deposit insurance legislation were also met by the agreed deadlines.

- Discussions: Discussions were held in Bucharest during July 29-August 10, 2009. The mission met with President Basescu, Prime Minister Boc, Finance Minister Pogea, Central Bank Governor Isarescu and other senior officials, the main contenders in the upcoming presidential elections, representatives of labor and business organizations, and of financial institutions. The staff team comprised J. Franks (head), A. Cebotari, B. Yontcheva (all EUR); N. Hobdari (SPR); F. Hasanov (FAD); O. Frecaut and L. Zanforlin (MCM). T. Lybek (Resident Representative) assisted the mission and Ms. Siegel (HRD) participated. Staff from the EC and the WB also joined the discussions. 


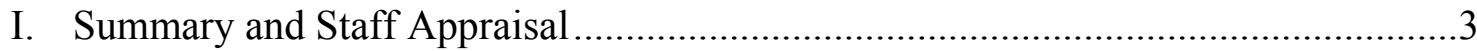

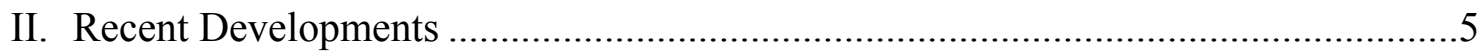

III. Policy Discussions ....................................................................................... 7

A. Revised Macroeconomic Framework ....................................................

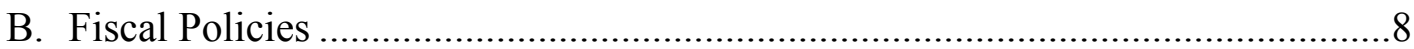

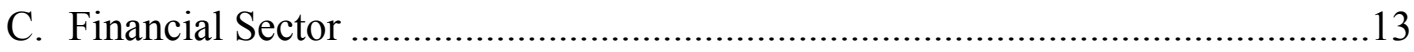

D. Monetary and Exchange Rate Policies ........................................................... 14

IV. Program Modalities and Safeguards Assessment ................................................15

Box

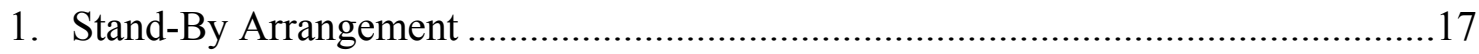

Figures

1. Selected Economic Indicators.......................................................................18

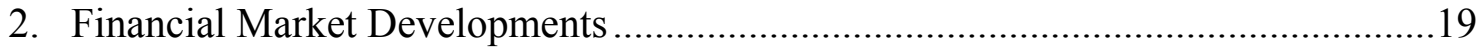

3. Selected Monetary Developments ...................................................................20

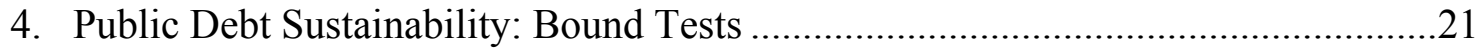

5. External Debt Sustainability: Bound Tests .......................................................22

Tables

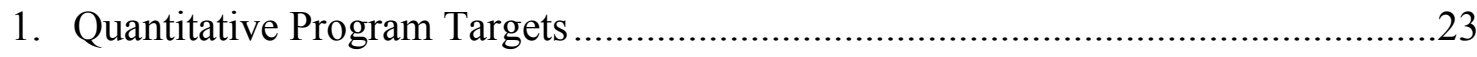

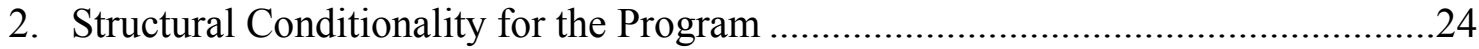

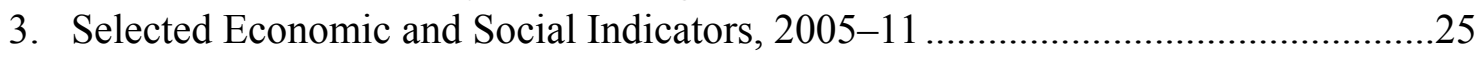

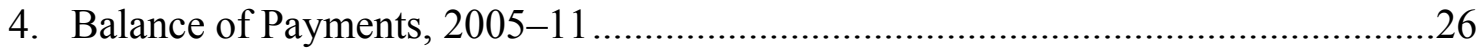

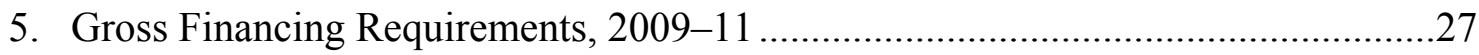

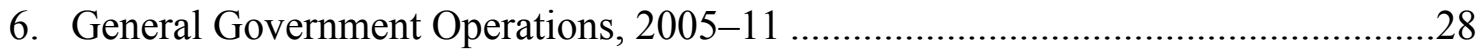

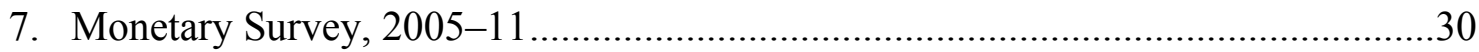

8. Schedule of Reviews and Purchases ...................................................................... 31

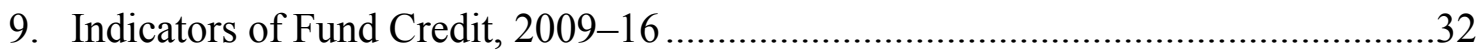

10. Public Sector Debt Sustainability Framework, 2004-14 .....................................33

11. External Debt Sustainability Framework, 2004-14 …..........................................34

Attachments

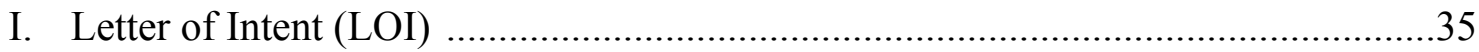

II. Technical Memorandum of Understanding (TMU) .........................................46 


\section{SUMMARY AND StAFF APPRAISAL}

1. Policies have remained broadly on track despite a significant deterioration in the economic environment since the program was agreed. The decline in economic activity was deeper than anticipated in the program. Real GDP contracted by 7.6 percent in the first half of 2009 , compared to $2 \frac{2}{3}$ percent projected under the program, on account of a sharp drop in domestic demand, especially consumption. This posed a particular challenge for public finances, where weakening revenues required sharp temporary cuts in spending to meet what turned out to be structurally tight targets. Nevertheless, initial policy implementation has been largely in line with the program, with all quantitative performance criteria and indicative targets for end-June 2009 having been met, with the exception of the ceiling on general government domestic arrears, for which the authorities request a waiver (Table 1). Staff supports this waiver on the basis of corrective actions being taken. Inflation was within the inner band of the inflation consultation mechanism and all structural benchmarks to end-August 2009 have been met (Table 2). Based on this performance, and on the further commitments contained in the attached Letter of Intent (Attachment I), staff supports the authorities' request for completion of the first review under the Stand-By Arrangement.

2. The sharper economic downturn requires a recalibration of the policy setting under the program, particularly with a view to striking an appropriate balance between fiscal policies' short-term response to the cycle and medium-term consolidation objectives.

- $\quad$ Fiscal Policies. To avoid a large negative impulse to demand, fiscal targets would be relaxed to accommodate about three quarters of the cyclical deterioration in the deficit in 2009. The need to continue the fiscal consolidation towards the 3 percent deficit target, however, required an additional adjustment effort and comprehensive structural measures that would ensure sustainability over the medium term. Therefore, the revised program: (i) focuses the additional adjustment effort on measures that would secure permanent reductions in government spending (such as rationalization of public sector institutions, employment and costs); (ii) strengthens structural reform commitments in the wage and pension areas; and (iii) calls for new reforms to strengthen controls over the performance of units outside central government that pose significant fiscal risks (local governments, self-financed institutions and SOEs). The latter set of measures is also intended to tackle the potential accumulation of arrears outside the central government, which early indicators suggest may have been problematic in early program implementation. About half of the additional gap that results from the relaxation of the fiscal targets would be financed from Fund disbursements during the rest of 2009, with the remainder covered by financing in private markets.

- Monetary policies. Monetary and exchange rate policies will remain anchored on targeting inflation over the medium term. The fall in actual and projected inflation allowed the National Bank of Romania (NBR) to prudently relax its monetary stance 
so far this year. Looking forward, while there is some room for further easing, staff believe a cautious approach is warranted as inflation in Romania remains well above the EU average, further price pressures may emerge, and the economy remains vulnerable to significant depreciation pressures and capital outflows.

- $\quad$ Financial policies. The measures envisaged in the original program, based largely on the 2008 FSAP update recommendations, remain appropriate to tackle the challenges posed by the crisis for the financial system. Reforms to enhance NBR's crisis management powers and improve the deposit insurance scheme have been implemented, although staff encouraged the authorities to bring forward the date when the new deposit insurance regulation comes into effect and to improve the sources of funding for the scheme. Reforms to strengthen the bank resolution framework have been postponed by a few months to give additional time to harmonize them with EU requirements. The authorities remain vigilant to any signs of stress in the banking sector and will act promptly if needed.

\section{While most of the initial program targets were met, pressures building on the} fiscal front will require vigilance going forward. In particular, the composition of expenditures in the first half of the year was cause for concern, with overruns in current spending - mainly in the public wage bill — offset by underexecution of the capital budget. This overshooting of current spending - particularly outside the central government - could endanger compliance with the fiscal objectives and lead to further undesirable cuts in capital spending unless reforms are successful at bringing it under better control. Similarly, the accumulation of arrears in both central and local governments suggests the need for stronger commitment controls and tighter budget execution procedures. Finally, pressures are also increasing to use sovereign guarantees to support economic activity in the face of tight budget constraints. While the program ceiling on guarantees limits the associated near-term risks, the authorities should channel guarantees towards projects with highest net benefits, such as those financed by EU structural funds, and should ensure that the fiscal responsibility legislation currently under preparation puts in place medium-term controls on contingent liabilities.

4. Risks to implementation of the program, therefore, remain. While laudable, several of the authorities' proposed fiscal remedies - such as cuts in public employment and tighter controls on current spending in decentralized entities - may prove difficult to achieve in the short timeframe contemplated. Political risks to the program are also rising. The severity of the downturn and the upcoming November presidential elections are straining cohesion within the coalition government and could weaken support for needed adjustment measures and structural reforms. To address these concerns, the authorities recognize the need for continued careful program monitoring and for ongoing policy dialogue with the Fund, and are committed to making policy adjustments that may become necessary. 


\section{RECENT DEVELOPMENTS}

5. Romania is in the midst of a severe recession. Economic activity contracted by 7.6 percent in the first half of 2009 , compared to $2 \frac{2}{3}$ percent projected under the program. This brings the cumulative output loss during this crisis to 8.4 percent since its peak in the second quarter of 2008, compared to an average loss of 6.3 percent in the region, excluding the Baltics (text figure). The decline is spearheaded by a sharp contraction in domestic demand, especially consumption, as bank credit retracted, income growth ground to a halt, and confidence plummeted (Figure 1). The external sector has recently had a positive impact due to sharply contracting imports. The pace of economic decline has begun to slow in the second quarter of 2009, but is not expected to turn positive until late-2009 or early 2010.
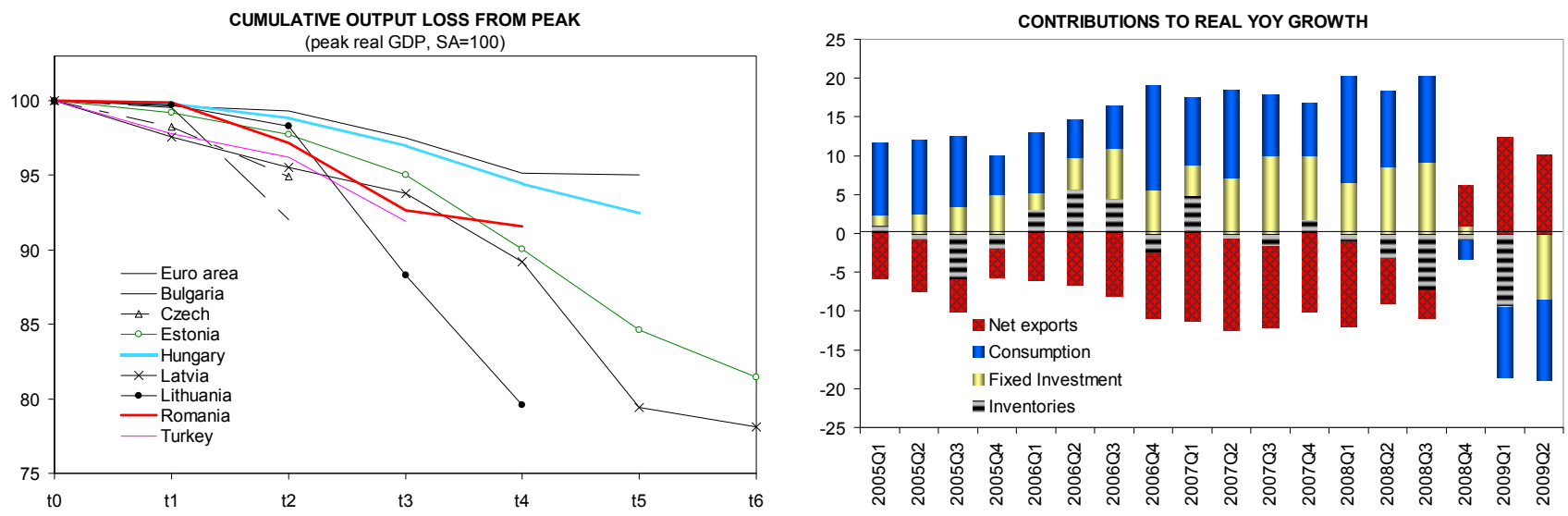

Source: Eurostat, Fund staff estimates.

\section{The contraction in domestic demand has set off a sharp correction in external imbalances and helped ease pressures on inflation.}

- $\quad$ The current account deficit shrunk in the first half of the year to about a quarter of its level during the same period last year ( $€ 2.4$ billion), mainly reflecting a contraction in the trade balance as imports plummeted faster than exports ( 37 and 20 percent, respectively). The pace of adjustment has been much faster than anticipated in the original program, although it has moderated somewhat in recent months (text figure).

- Headline inflation eased from 6.9 percent in February to 5.1 percent in July 2009, helped by slacking domestic demand and by supply factors, such as the recent stability of the exchange rate, cuts in administered prices, and declining food prices. The latter has also been the main factor behind the deceleration in core inflation to 4.6 percent in July, which otherwise would have shown greater persistence despite the widening output gap. 

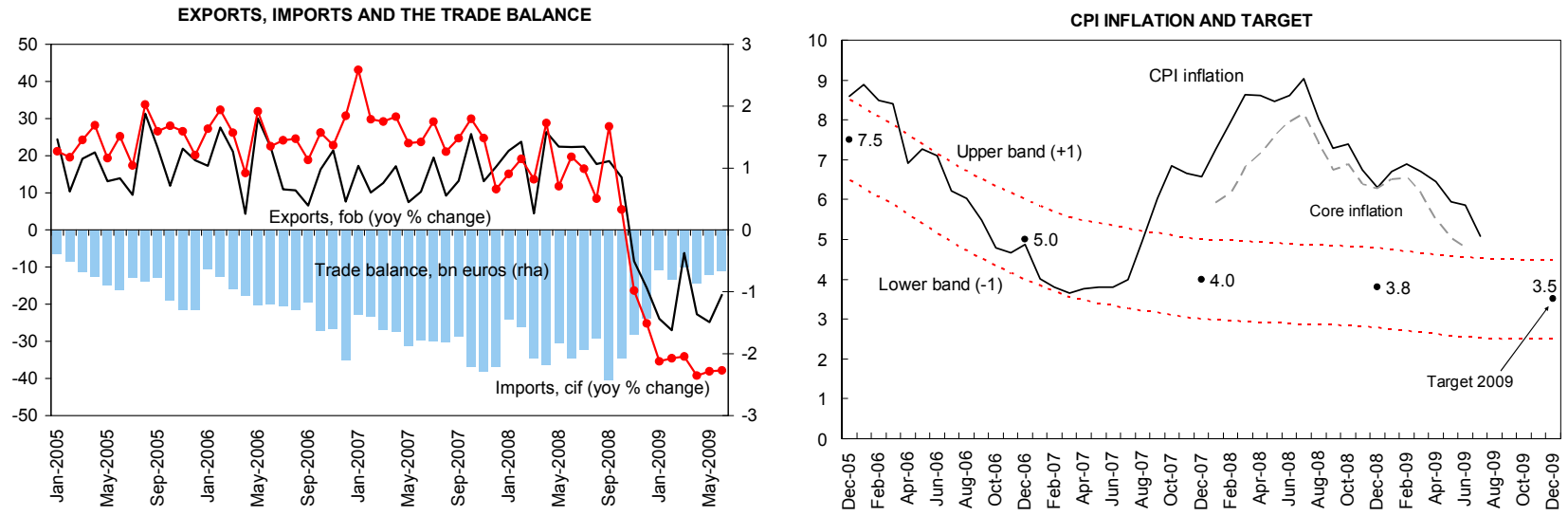

Source: Haver, NBR, and Fund staff estimates.

7. Financial stress has eased significantly with the international support package and recovering global financial markets, but credit conditions remain tight (Figure 2). Since agreement on the SBA program was announced, the leu/€ exchange rate has remained broadly stable, allowing the central bank to stop intervening to support the currency and to inject significant leu liquidity into the banking system. As a result, bank funding costs have eased in domestic and external markets: interbank market rates have converged towards monetary policy rates and, in line with a global recovery in credit markets, the CDS premium has declined some 400 basis points, helping ease bank lending and deposits rates. The stock market continues to improve, up over 120 percent from its February trough and returning close to its pre-Lehman level. A financial stress index, which summarizes volatility across various markets, spiked in late 2008 and early 2009, but has since eased back in line with that of Romania's peers. Lending conditions remain tight, however, due to stricter lending standards, worsening asset quality and lower demand, and real credit growth decelerated sharply from 25 percent yoy at end-2008 to 5 percent by mid-2009.

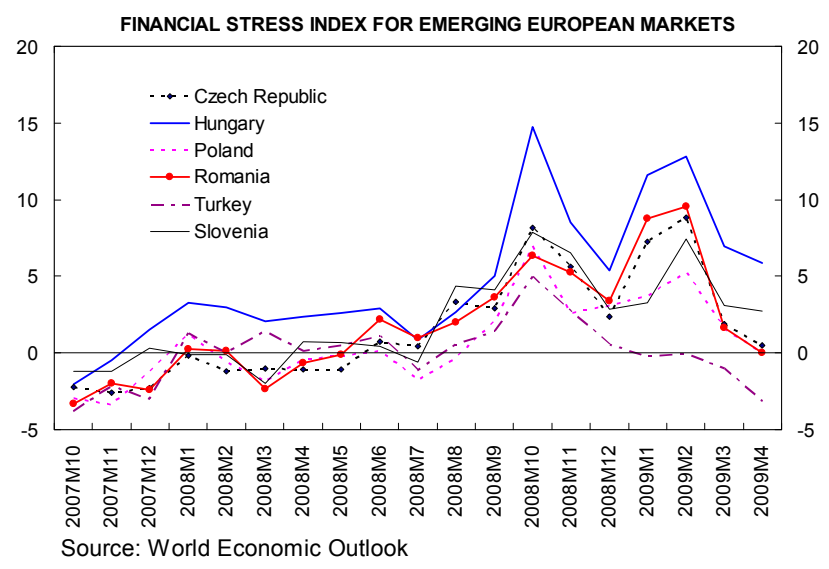

\section{The banking system has weathered the downturn relatively well so far, but} deteriorating credit quality is expected to put pressure on banks' capital going forward. As of end-June 2009, the average capital adequacy ratio for the system was at 13.5 percent, broadly stable over the past two years (text table). The ratio was supported by retained 2008 earnings and capital increases in several banks, leaving all banks with a ratio above 10 percent (compared to the regulatory minimum of 8 percent). However, credit quality continues to deteriorate, with NPLs (doubtful and loss) almost doubling in the year to June to $11 \frac{3 / 4}{4}$ percent. Despite a similar increase in associated provisioning during the first half of 2009, the system as a whole remained slightly profitable thanks to wider interest margins 
and reduced costs. Asset quality will likely deteriorate further with rising unemployment and declining corporate profitability, putting additional strain on banks' capital positions going forward. Following the April 2009 stress-tests, the majority of the banks with expected future capital needs in 2009 and 2010 have already increased their own funds to a level that will enable them to maintain their capital adequacy ratio above 10 percent over the entire program period, while others have made significant Romanian Banking System - Core Indicators

\begin{tabular}{lcccc}
\hline & Dec-07 & Jun-08 & Dec-08 & Jun-09 \\
\hline Capital Adequacy Ratio & $13.8 \%$ & $12.8 \%$ & $13.8 \%$ & $13.5 \%$ \\
Leverage Ratio & $7.3 \%$ & $7.3 \%$ & $8.1 \%$ & $6.9 \%$ \\
$\quad$ (Tier I capital/assets) & & & & \\
Non-performing loans/Loans & $4.0 \%$ & $4.7 \%$ & $6.5 \%$ & $11.8 \%$ \\
Return on Assets & $1.0 \%$ & $1.4 \%$ & $1.6 \%$ & $0.1 \%$ \\
Return on Equity & $9.4 \%$ & $15.8 \%$ & $17.0 \%$ & $0.6 \%$ \\
\hline
\end{tabular}
progress in that direction. ${ }^{1}$

9. External financing has held up better than expected. Although inflows declined during the first half of 2009 - with FDI inflows falling by about 45 percent compared to 2008, and a less-than-full rollover of maturing external debt - net capital inflows were better than anticipated under the program. Rollover of external debt was about 82 percent in the first half of the year, somewhat above program projections, with rollover rates for both banks and corporates improving significantly in the second quarter, following agreement on the program (Table 5). FDI inflows were also stronger than projected in the program, and more than covered the current account deficit in the first half.

\section{Policy Discussions}

\section{A. Revised Macroeconomic Framework}

10. The outlook for $\mathbf{2 0 0 9}$ has deteriorated significantly relative to the original program, although prospects for a faster recovery in 2010 have improved:

- $\quad$ Growth. GDP is now expected to contract by around 81/2 percent in 2009 (compared to 4 percent in the program) and to recover modestly to $1 / 2$ percent in 2010 (up from near zero in the program) (Table 3). This reflects largely the carry-over effects from developments in the first half of the year, as quarterly growth is projected to level off at near zero in the remainder of 2009 and turn positive in 2010 . The recovery is likely to be slow, however, with rising

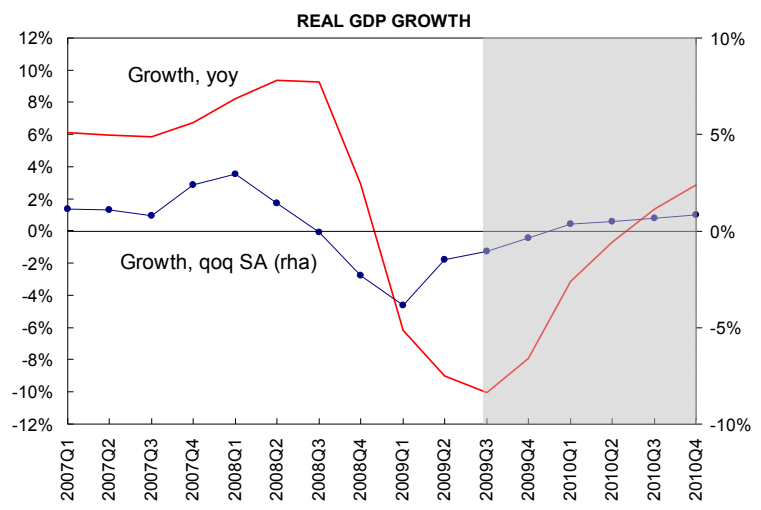

\footnotetext{
${ }^{1}$ The potential capital needs estimated in April 2009 remain valid, as the worse-than-expected growth performance was mitigated by a more appreciated exchange rate and lower interest rates in their impact on NPLs and capital adequacy.
} 
unemployment, deleveraging by households and corporates, and increasing NPLs in the banking system likely to weigh on domestic demand. The medium-term outlook remains broadly unchanged from the original program, with the output gap expected to close by $2013-14$.

- $\quad$ Current account. As a result of the deeper recession, the current account has been adjusting faster than expected. Staff now projects the current account deficit to contract from $12^{1 / 2}$ percent of GDP in 2008 to about 5 $\frac{1}{2}$ percent in 2009 (compared to $71 / 2$ percent under the program) (Table 4 ).

- $\quad$ External financing. The outlook for the capital account is better than originally projected, reflecting higher FDI, better rollover rates, and prospects for a Eurobond issue later in 2009. Together with the faster-than-projected adjustment in the current account, this will allow for a larger accumulation in international reserves (Table 5).

\section{The outlook continues to be subject to exceptional uncertainties, but risks are} broadly balanced. Downside risks include: (i) negative feedback loops between real and financial sectors; (ii) a poor agricultural year in 2009, which would weigh heavily on the growth outlook starting from the third quarter of 2009; (iii) another bout of regional financial market turbulence that could trigger further capital outflows and destabilizing exchange rate depreciation; and (iv) political developments, with presidential elections scheduled for November, which could slow program implementation. On the upside, a faster than anticipated recovery of foreign or domestic demand could boost economic activity.

\section{B. Fiscal Policies}

\section{Despite pressures on public finances from weakening economic activity, performance in the first half of the year was broadly in line with the program. The} overall deficit was 2.9 percent of estimated GDP in the year to June, in line with the program. However, revenues fell by some 12 percent in real terms relative to the same period of last year and by 0.7 percentage points of GDP relative to the program, with the bulk of the decline reflecting a sharp fall in VAT, social security contributions and nontax revenues. The revenue shortfall was temporarily offset by strict expenditure controls, but significant spending pressures accumulated. In particular, current spending outside the central government (local governments and self-financed entities, such as universities and hospitals) was not reined in by measures to reduce bonuses and staffing, ${ }^{2}$ and the impact of the large increases in wages and pensions in the last months of 2008 was higher than anticipated. Other fiscal quantitative targets were met as well, with the exception of the target on the nonaccummulation of general government arrears, which was exceeded (by 0.1 percent of

\footnotetext{
${ }^{2}$ Personnel spending in these sectors increased by up to 20 percent, compared to 6 percent in the central government.
} 
GDP) due to increased payment delays within and outside the central government. The authorities aim to clear all arrears accumulated during this year by end-September 2009 and the remaining stock of arrears (which turned out higher than estimated when the program was approved) by end-2010, address the weaknesses that led to the accumulation of arrears in the first place by initiating a review, with FAD technical assistance, of the budget execution procedures and commitment control systems, and strengthen the financial framework for local governments (see below). On the basis of these corrective actions, staff supports authorities' request for the waiver of nonobservance of the performance criterion.

\section{In the absence of further measures, the $\mathbf{2 0 0 9}$ deficit would increase significantly} with the cyclical downturn. The deficit would jump to 8.1 percent of GDP from 4.6 percent envisaged in the program, due to a cyclical fall in revenues (including lower tax yields). This assumes that the overruns in current spending outside the central government would be clawed back to program levels due to balanced budget requirements and that capital spending will be somewhat lower than budgeted given capacity constraints (Table 6).

\section{The revised program aims to strike an appropriate balance between fiscal} policies' short-term response to the cycle and medium-term consolidation objectives. With a significant fiscal adjustment already underway in 2009, a further large adjustment would exacerbate the downturn, while abandoning consolidation towards the 3 percent medium-term deficit target could be detrimental to market confidence and to the euro adoption prospects. The staff and the authorities agreed, therefore, that accommodation of most of the cyclical deterioration in the deficit in 2009-10 - accompanied by some further consolidation and by measures that would assure the sustainability of the adjustment-would provide the suitable balance between the short- and medium-term objectives.

- $\quad$ For 2009, the revised program targets a deficit of 7.3 percent of GDP, accommodating about $2 \frac{2}{3}$ percent of GDP of the cyclical deterioration relative to the program and requiring a further 0.8 percent of GDP in adjustment measures in the remainder of 2009 (text table). While about half of this adjustment will be secured by a further retrenchment imposed by balanced budget rules outside the central government to offset the revenue shortfalls, emergency measures will also be required including: suspension of premia and overtime payments; a 10-day unpaid furlough (or an equivalent reduction in working hours) across all levels of government; launching restructuring of state agencies, many of which will be abolished or merged with their respective line ministries, and lower capital spending. The approval of these measures, including a revised 2009 budget, is a prior action for the completion of the review.

- $\quad$ For 2010, the revised program seeks to reduce the deficit to below 6 percent of GDP, equivalent to a structural adjustment effort of $2 \frac{1}{3}$ percent of GDP. The measures contemplated focus largely on expenditure cuts given the buildup in spending over the last few years and include: (i) rationalizing public sector institutional structure, employment, and costs, which are expected to lead to permanent savings in the wage 
bill (in part through a significant reduction in employment); (ii) pension savings from widening the contributor base under a new pension law, and a better targeting of disability pensions and early retirement provisions through stricter enforcement of existing rules; (iii) savings from improved targeting of social assistance programs and the consolidation of more than 200 benefits, while providing additional resources to boost social safety nets (LOIף17); (iv) spending restraint through a freeze in wages during 2010 (except for those earning less then RON705 per month), pensions (excluding social ones), goods and services, and certain transfers during 2010; and (v) an already approved revaluation of property taxes and increased excises on tobacco and fuel (text table). A 2010 budget in line with these commitments is expected to be submitted to parliament in October 2009, and its approval will be a structural benchmark for end-2009.

Fiscal program, original and revised (in percent of GDP)

\begin{tabular}{lrr}
\hline & 2009 & 2010 \\
\hline Overall deficit - original program & 4.6 & 3.6 \\
Overall deficit - revised macroframework, no measures & 8.1 & 7.9 \\
Overall deficit - revised program & 7.3 & 5.9 \\
Required adjustment effort, of which: & $\mathbf{0 . 8}$ & $\mathbf{2 . 0}$ \\
Revaluation of property value & & 0.1 \\
Increase in tobacco and fuel excises & 0.2 \\
Unpaid 10-day furlough & 0.3 \\
Cuts in capital spending (- = increase) & 0.2 & -0.1 \\
Reduction in personnel spending (wage freeze, premia, employment cuts, etc) & 0.1 & 0.8 \\
Freeze in goods and services, pensions, and some transfers & 0.2 & 0.7 \\
Cuts in goods and services and other expenditure & & 0.2 \\
Pension reform savings & 0.1 \\
Memorandum item: & & 0.2 \\
Additional unemployment benefits & 0.2 \\
\hline
\end{tabular}

- $\quad$ The accommodation of larger deficits will widen the fiscal financing gap (and the public debt) by about 4.6 percent of GDP (€5.3billion) during 2009-10. The authorities plan to issue a $€ 0.5$ billion Eurobond in September 2009, but a significant shortfall would remain. To avoid crowding-out pressures in the domestic markets, half of the IMF disbursements through the remainder of 2009 (SDR 3.1 billion) would be used for budgetary purposes. Despite the larger deficits and debt in the near terms, fiscal sustainability is not a concern in the program scenario, as debt peaks at about 34 percent by 2011 and will be on a downward trend thereafter (Figure 4 and Table 10).

\section{Higher near-term deficits will be counterbalanced by comprehensive structural measures that would secure sustainable reductions in spending over the medium term.}

- Wage reform. The authorities are drafting a unified public wage law to be passed by October 2009. The objective of the legislation is to provide a transparent, fair, and uniform wage system for all civil servants, while securing significant savings over the medium term. To address concerns that early drafts of the law would raise, rather than lower, the wage bill, the revised program strengthens commitments in this area by 
calling for: (i) the inclusion in the legislation of safeguards that would ensure a reduction of the public wage bill over the medium-term, including specific annual limits for the wage bill with a view to progressively reducing it from 9 to about 7 percent of GDP within five years (to levels prevailing before the last few years' excesses), ${ }^{3}$ a freeze in most wages during 2010, and conditioning future increases in public wages on the personnel cuts needed to reach the wage bill targets for 2011-15; (ii) basing the new pay and grade scales on principles consistent with best practices; and (iii) requiring full costing of the legislation by independent experts before its submission to parliament (LOI 12 ). The reform is now envisaged to unfold in two stages, with an organic public wage law laying out the fundamental principles of the new system to be approved by end-October 2009, and subsequent implementing legislation detailing the elements of this system to be approved by September 2010 . The World Bank is providing assistance to the authorities on this legislation under their DPL loan.

- $\quad$ Fiscal Responsibility Legislation (FRL). The authorities are well advanced in drafting new FRL legislation, which is benefiting from Fund technical assistance and advice from the EC, and is expected to be submitted to parliament by end-November, with approval by March 2010 (see Country Report No. 09/183 for proposed content of the legislation). Follow-up technical assistance from the Fund on the implementation of the FRL is expected in early 2010, with particular focus on strengthening budget execution procedures and commitment controls so as to enable a tighter management of arrears across the general government.

- $\quad$ Local governments. To minimize fiscal risks from local governments and ensure burden-sharing in the adjustment process, the revised program includes new measures to strengthen control over local government finances. ${ }^{4}$ This will involve legislative changes, through the FRL and local government legislation, to: (i) give central government powers to require adjustment measures to tackle overruns and fiscal imbalances in exchange for financial support; (ii) introduce costing and employment norms to achieve savings in current spending; (iii) prohibit movement of budget allocations from capital to current spending; (iv) introduce a legal framework for local government insolvency, in part to reduce moral hazard associated with an implicit government guarantee of local government obligations; and (v) strengthen

\footnotetext{
${ }^{3}$ This reduction in the wage bill would be consistent with a modest increase in average public sector wages during the five-year period under unchanged employment. Larger wage increases would need to be accommodated by cuts in personnel.

${ }^{4}$ Local governments enjoy constitutional autonomy in setting their own budgets, within the constraints of balanced current budget rules and strict limits on borrowing. However, they sometimes overspend, overestimate revenues, or run arrears and then appeal for help from the central government.
} 
the local government oversight units in the central government (new structural benchmark for end-June 2010; LOIף14).

- $\quad$ State-owned enterprises (SOES). The situation of key public enterprises has deteriorated significantly with the downturn and as a result of large wage increases negotiated at end-2008, and is putting pressures on the general government finances. The revised program envisages legislative and regulatory changes to strengthen government control over SOE performance and improve their governance framework, including: (i) improvements in the SOE budgeting process (to avoid pressures on the wage bill from collective bargaining agreements); (ii) introduction of direct government control over wage-setting at SOEs receiving public subsidies;

(iii) introduction of automatic sanctions for the nonobservance of the budget or of the management performance contracts; and (iv) giving central government tools to require improvements in SOE financial performance if breaching fiscal rules or requesting additional budget resources (new structural benchmark for end-June 2010; LOIV15). The authorities also agreed to refine the monitoring system of the most problematic SOEs, with a view to setting semiannual targets on their performance at the next review.

- Pension reform. The authorities are drafting pension reform legislation, with assistance from the World Bank. The reform aims at securing the system's long-term sustainability, and is expected to be passed by end-2009. To secure achievement of the reform's objectives, the revised program includes additional commitments by the authorities to: (i) properly cost the draft legislation to ensure long-term savings; (ii) eliminate the costly and inequitable special regimes established for certain civil servants; (iii) revise conditions for early retirement to ensure that incentives provide an actuarially fair system; and (iv) effectively monitor the allocation of disabilityrelated pension rights to ensure better control over fraudulent pension claims (LOIף13).

- Tax administration reforms. Progress in revenue administration is essential to recouping the loss in revenue yield related to the economic cycle and meeting the fiscal targets. Following recommendations from a recent IMF technical assistance mission, the revised program envisages increased focus on addressing VAT noncompliance and fraud, reforming the VAT refund process to tackle increasing delays in settling refunds, improving management of growing tax arrears, and increasing control of the largest taxpayers (LOIף16). Approval of the necessary internal regulations and legislation to implement these reforms will be a new structural benchmark for end-March 2010.

\section{The authorities are increasingly relying on public guarantees to support} economic activity. They are expanding credit guarantees to enterprises and have recently 
launched a $€ 1$ billion mortgage guarantee program to support the mortgage and construction sectors. ${ }^{5}$ To ensure that the existing ceilings do not hamper the financing the counterpart payments of investment projects financed by the EU or other multilateral institutions, the revised program envisaged an increase in these ceilings by 0.3 percent of GDP in 2009 and $1 / 2$ percent in 2010, with the increase targeted exclusively to securing cofinancing.

\section{Financial Sector}

\section{The parents of the largest foreign-owned banks in Romania have demonstrated} continued commitment to their Romanian subsidiaries. The nine largest banks, with a market share of 70 percent, have all sent bilateral letters to the NBR confirming the commitments made in Vienna in March 2009 and in Brussels in May 2009 to maintain overall exposure to the country during the program period and recapitalize their subsidiaries as needed. While actual exposures to their Romanian subsidiaries have fluctuated - with an average reduction of 3.4 percent between March and June 2009—most banks maintained overall exposure or restored it after end-June through increased claims on the Romanian sovereign. ${ }^{6}$ The NBR is in the process of setting up, in consultation with the banks, a reporting framework that would allow a more comprehensive monitoring of overall exposures, including those that do not appear in the local banks' balance sheet (e.g., parent group direct exposure to Romanian entities).

\section{The authorities continue to improve the safety net available to deal with}

financial distress, in line with the recommendations of the 2008 FSAP update. They have enhanced the NBR's powers to request capital increases and restrict dividend distribution for weak credit institutions, in line with the structural benchmark for June 2009. They have also amended the deposit insurance legislation to broaden grounds for activation and reduce the deadline for payouts to 20 business days by end-2010 (thereby meeting the August 2009 structural benchmark), and are considering further improvements in the financing regime to enhance official support for deposit insurance where funding fees prove insufficient. ${ }^{7}$ Additional improvements should be considered to avoid that a bank is automatically placed under a special administration regime upon activation of the deposit insurance. The

\footnotetext{
${ }^{5}$ The program involves state guarantees for first home mortgages, both in leu and foreign currency, of up to $€ 60,000$, reduced upfront payments and interest rates, and a fee of up to 2 percent of the guaranteed amount. The program is intended to run for 18 months.

${ }^{6}$ Banks' commitments envisage maintaining overall group exposure to Romania throughout the program period, starting March 2009. It was agreed during the May 2009 meeting in Brussels that semiannual follow-up meetings will be held with the parent banks to review the commitments in light of evolving circumstances in Romania.

${ }^{7}$ The current funding regime of the guarantee fund envisages the use of funding fees and of contingent credit lines from the banks before official funding is tapped. Staff encouraged the authorities to rely more heavily on accumulated bank fees and on facilities providing exceptional access to government funds, while eliminating credit lines from the banks as a source of funding.
} 
authorities are working on streamlining and strengthening the special administration regime to provide an effective bank resolution framework for problem banks, but harmonizing desired reforms with EU legal framework has proved more complex than anticipated, and they now expect to complete these reforms in early 2010 (end-March 2010 structural benchmark). For overly indebted households, banks have implemented a wide range of decentralized approaches to debt rescheduling and restructuring, with a view to preserving credit discipline, that staff consider as appropriate for the time being. Thus, staff share the authorities' assessment that public action is not needed at this time, but encouraged them to continue to monitor the results closely.

\section{The NBR is continuing to improve the banking supervisory and regulatory}

framework. Liquidity requirements and governance rules applicable to banks have been enhanced, including by requiring a higher coverage of short-term liabilities with short-term assets. Before further amending liquidity regulations, including to differentiate liquidity requirements by currency, the NBR will conduct a more comprehensive impact study and will consult the banking association about the results. Permanently raising the minimum level of the capital adequacy ratio from 8 percent to 10 percent remains a medium-term objective. The authorities remain committed to bringing the Romanian financial accounting standards into line with international practice and adopting the International Financial Reporting Standards (IFRS), and are consulting the Romanian Banking Association on the timetable.

\section{Monetary and Exchange Rate Policies}

\section{Moderating inflationary and exchange rate pressures have allowed NBR to} gradually ease monetary policy during 2009 (Figure 3 and Table 7). It has cut interest rates four times this year by a cumulative 175 basis points (to 8.5 percent), eliminated reserve requirements on long-term foreign currency liabilities, reduced reserve requirements on local and foreign currency liabilities of shorter maturities, and injected significant liquidity into the domestic money markets, mainly through repo facilities. The associated switch from a net debtor to a net creditor position vis-à-vis the banking system gave the NBR better leverage over the liquidity in the system during times of relative financial instability. Lack of intervention in currency markets and better-than-expected capital flows allowed the central bank to accumulate a comfortable margin in its NFA position, ending June some $€ 2 \frac{1}{2}$ billion above the program target.

21. Weak domestic demand will continue to dampen pressures on inflation, which is projected to fall to 4.3 percent by end-2009, somewhat below program projections and within the authorities' target band of 3.5 percent \pm 1 percent. The risks to the inflation outlook are tilted slightly upward, however, as a poor 2009 harvest may put pressures on food prices (which account for about 38 percent of the basket), underlying inflation has so far been slow to respond to the slackening demand, and potential further depreciation pressures could slow disinflation. 
22. Looking forward, the NBR will continue to adapt its monetary policy stance as inflation and conditions in the foreign exchange market permit. There is some room for further monetary easing, but a cautious approach is warranted, as inflation in Romania remains well above the EU average, further price pressures may emerge, and the economy is vulnerable to significant further depreciation pressures due to large unhedged foreign currency debt of the nonfinancial sector, especially households.

\section{Program Modalities And SAFeguards Assessment}

\section{The attached Letter of Intent (LOI) describes the authorities' progress in} implementing their economic program and sets out their commitments through June 2010.

- $\quad$ Some modifications to the program's conditionality are proposed (Tables 1-2). The floor on the general government's overall balance would be adjusted downward to partially accommodate the cyclical deterioration in revenues, and the ceiling on general government guarantees would be adjusted upward to allow a higher absorption of EU structural funds. The indicative ceiling on general government primary spending will be replaced with an indicative ceiling on current primary spending, to allow for an accelerated implementation of the authorities' investment program while helping to rein in overruns in current spending. In addition, the structural benchmark on the adoption of amendments on the bank resolution framework is proposed to be moved from November 30, 2009 to March 31, 2010, to allow time for harmonizing the reforms with the EU requirements.

- $\quad$ New structural benchmarks are proposed (Table 2): (i) approval of an agreed 2010 budget (end-December 2009); (ii) approval of legislation or regulations to implement tax administration reform (end-March 2010); and (iii) approval of reforms to mitigate fiscal risks from local governments and SOEs (end-June 2010).

- It is proposed that half of the remaining 2009 disbursements of SDR 3.1 billion be disbursed directly to the budget. This will help finance part of higher deficit proposed for 2009 (with the amount for 2010, if any, to be agreed in future reviews).

- No changes are proposed to the level of access or the schedule of purchases which remain adequate to address Romania's ongoing balance of payments needs (Table 8).

24. Romania's capacity to repay the Fund is expected to remain strong. While relative to the original SBA program the external debt will peak at a slightly higher level as a share of GDP due to sharper economic contraction in 2009, the level of reserves will also be higher in light of the faster contraction in the current account deficit and better developments in the capital account. More specifically, by the end of the arrangement, Fund exposure to Romania is projected to be about 10 percent of GDP, slightly over 30 percent of gross reserves (compared to about 40 percent under the original program) (Table 9). While this 
exposure remains large, the associated servicing risks are mitigated by the relatively low level of public debt. Direct public indebtedness is expected to remain relatively low (under 34 percent of GDP), with public external debt peaking at around 13 percent of GDP at end2010 (Table 10). Total external debt is projected to increase to about 71 percent of GDP at end-2010 (compared to 68 percent under the original program) from about 54 percent at end2008 , but the declining current account deficit and a return to economic growth would gradually reduce it to manageable levels in the medium term (Table 11). Romania's strong political commitment to the SBA program and its excellent track record servicing external obligations, also provide comfort that it will fulfill its financial obligations to the Fund in a timely manner.

25. The updated safeguards assessment of the NBR was completed in June 2009. The assessment found that in general the NBR continues to have a strong safeguards framework in place. The control environment is well established and the audit and financial reporting practices adhere to international standards. The mission recommended measures to safeguard the process of net foreign assets data reporting to the IMF and to strengthen audit oversight, especially over the external audit process. As advised by the safeguards mission, the NFA definition under the program would be revised going forward to reflect the collaterized nature of transactions with BIS.

\section{Fund staff has continued to cooperate closely with the staff of the European}

Commission (EC) and the World Bank (WB). Fund, EC and the WB staff have consulted each other regularly regarding economic and policy developments in Romania, and EC and WB staff participated in Fund meetings with the authorities. The EU disbursed its first tranche of its support in July 2009 ( $€ 1 \frac{1 / 2}{2}$ billion), and a second tranche is expected to be disbursed in December 2009 ( $€ 1$ billion), likely preceded by a joint IMF-EC mission. The WB will disburse its first tranche ( $€ 0.3$ billion) in September 2009, with the remaining tranches ( $€ 0.7$ billion) expected in 2010 . 


\section{Box 1. Romania: Stand-By Arrangement}

Access: SDR 11.443 billion.

Length: 24 months.

Phasing: SDR 4.37 billion was made available upon the Board's approval of the arrangement on May 4, 2009. The second tranche, subject to the completion of this (first) review, amounts to SDR 1.718 billion. The six subsequent disbursements are contingent upon completion of further quarterly reviews, starting from December 15, 2009 and ending on March 15, 2011, and will equal SDR 5.355 billion.

\section{Conditionality}

- Quantitative Performance Criteria

$>$ A floor on the change in net foreign assets

$>$ A ceiling on general government domestic arrears

$>$ A floor on the overall general government cash balance

$>$ A ceiling on general government guarantees

$>$ Non-accumulation of external debt arrears

- Quantitative Indicative Target

$>$ General government current primary spending

- A consultation band around the 12-month rate of inflation of consumer prices.

- Prior Actions

$>$ Approval of agreed fiscal measures for 2009, including revised 2009 budget. Prior action for Board consideration of first review.

- Structural Benchmarks

$>$ Passage of revised public compensation legislation. By October 30, 2009.

$>$ Presentation of fiscal responsibility legislation to parliament and preparation of an implementation plan. By November 30, 2009.

$>$ Passage of amendments to the banking and winding-up laws to enhance the bank resolution framework, in consultation with the IMF. By March 31, 2010.

$>$ Passage of revised pension legislation. By December 31, 2009.

$>$ Passage of agreed 2010 budget. By December 31, 2009.

> Approval of tax administration reforms. By March 31, 2010.

$>$ Approval of reforms of local government and SOE finances. By June 30, 2010 
Figure 1. Romania: Selected Economic Indicators
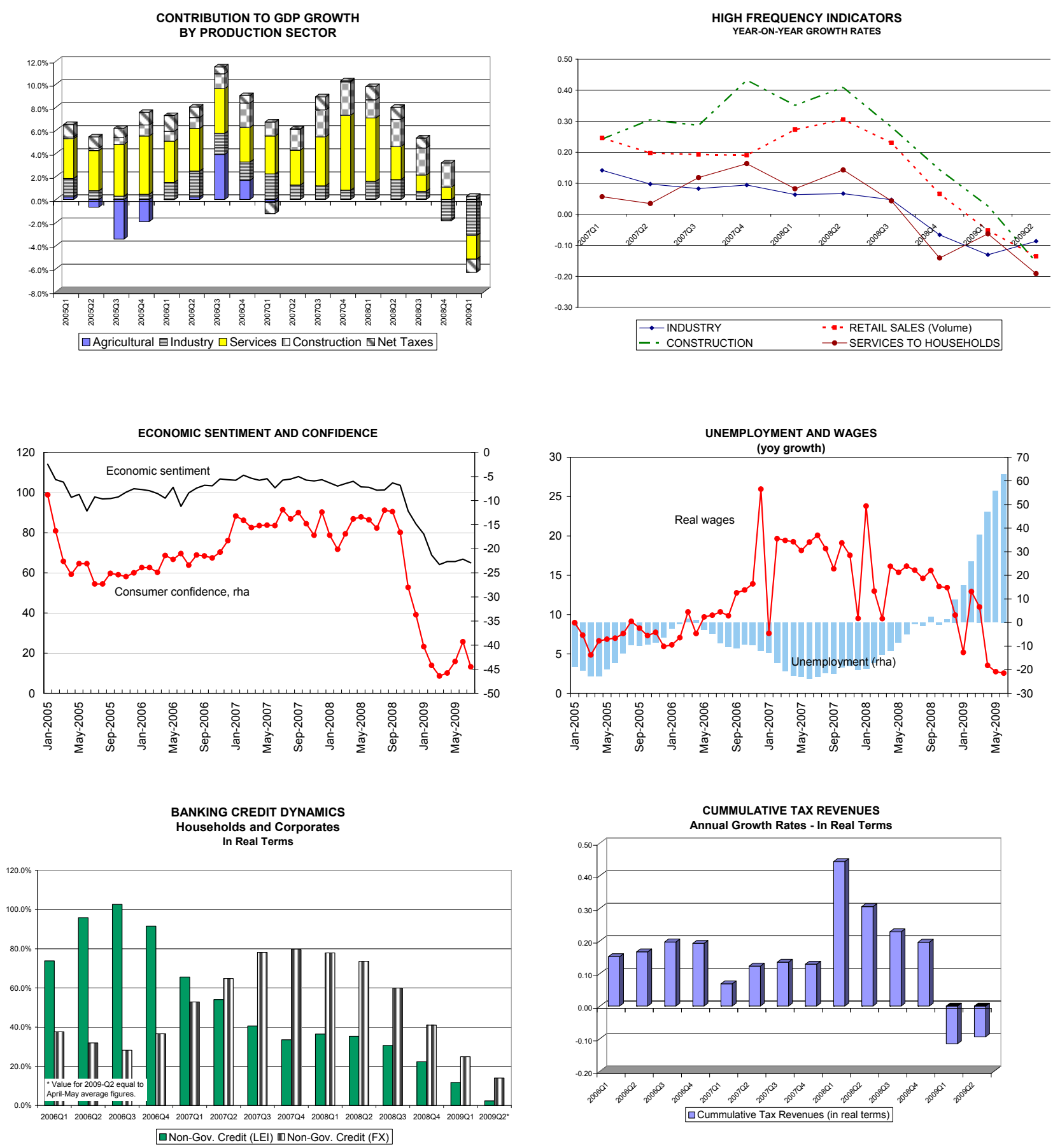
Figure 2. Romania: Financial Market Developments
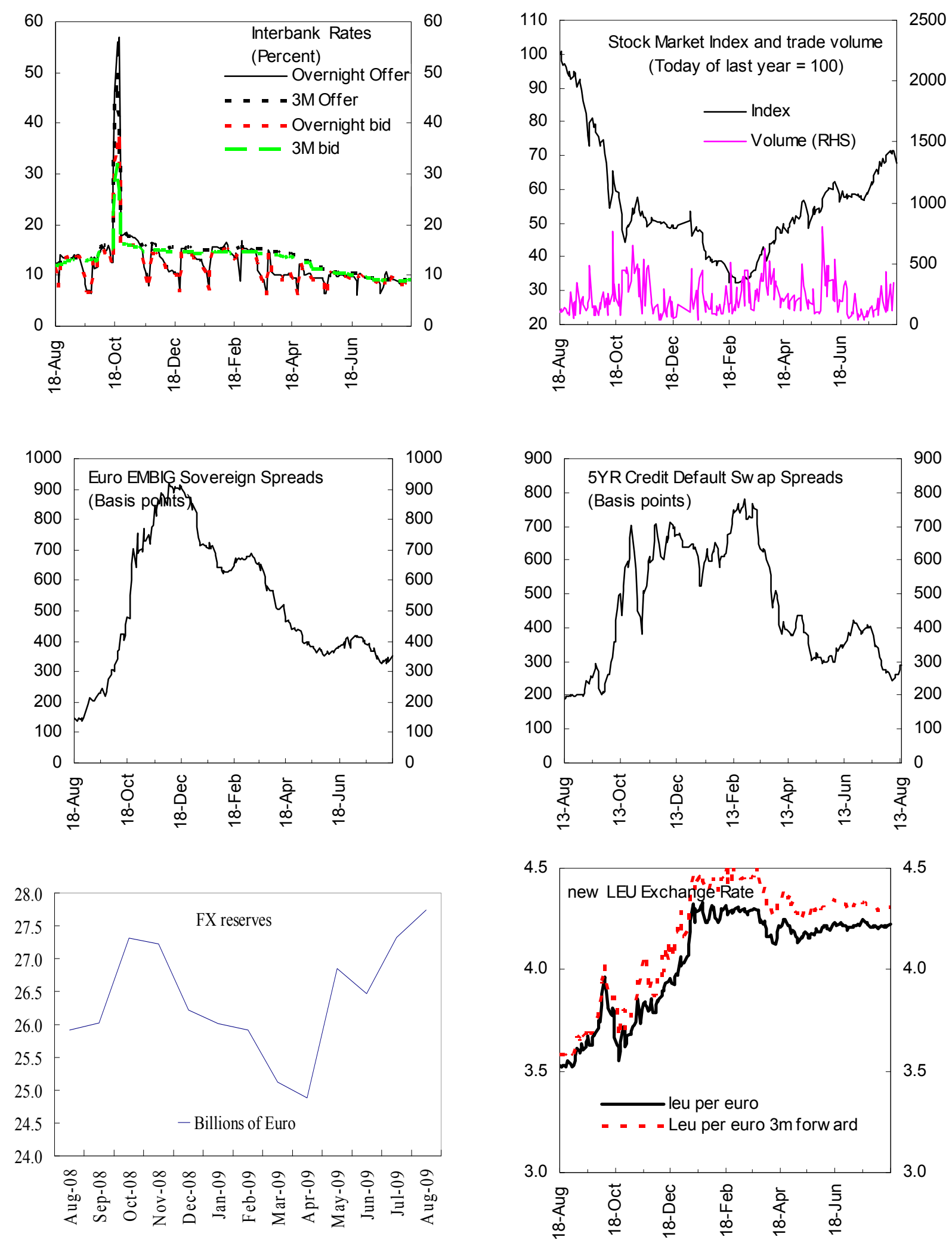
Figure 3. Romania: Selected Monetary Developments
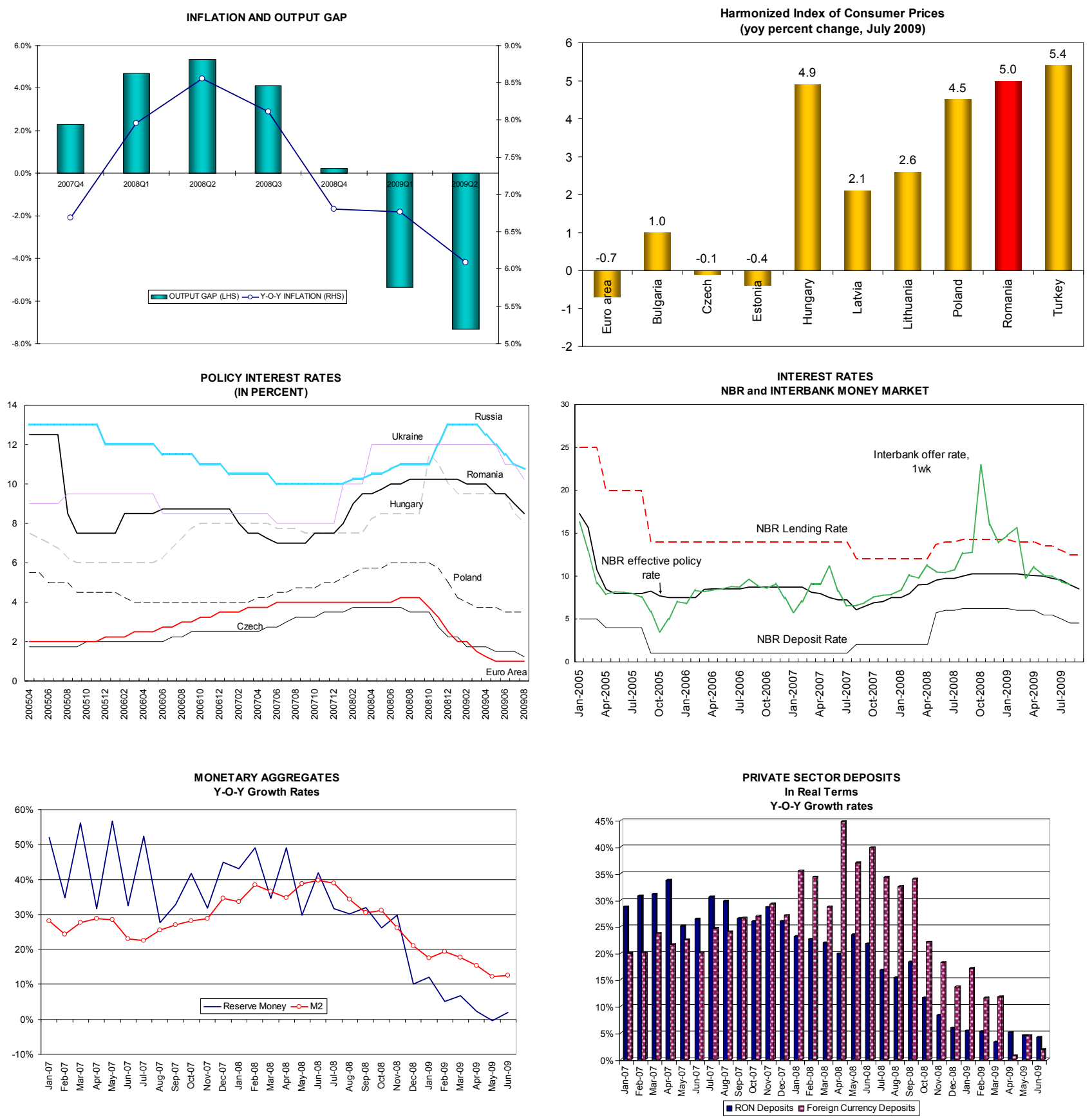
Figure 4. Romania: Public Debt Sustainability: Bound Tests 1/ (Public debt in percent of GDP)
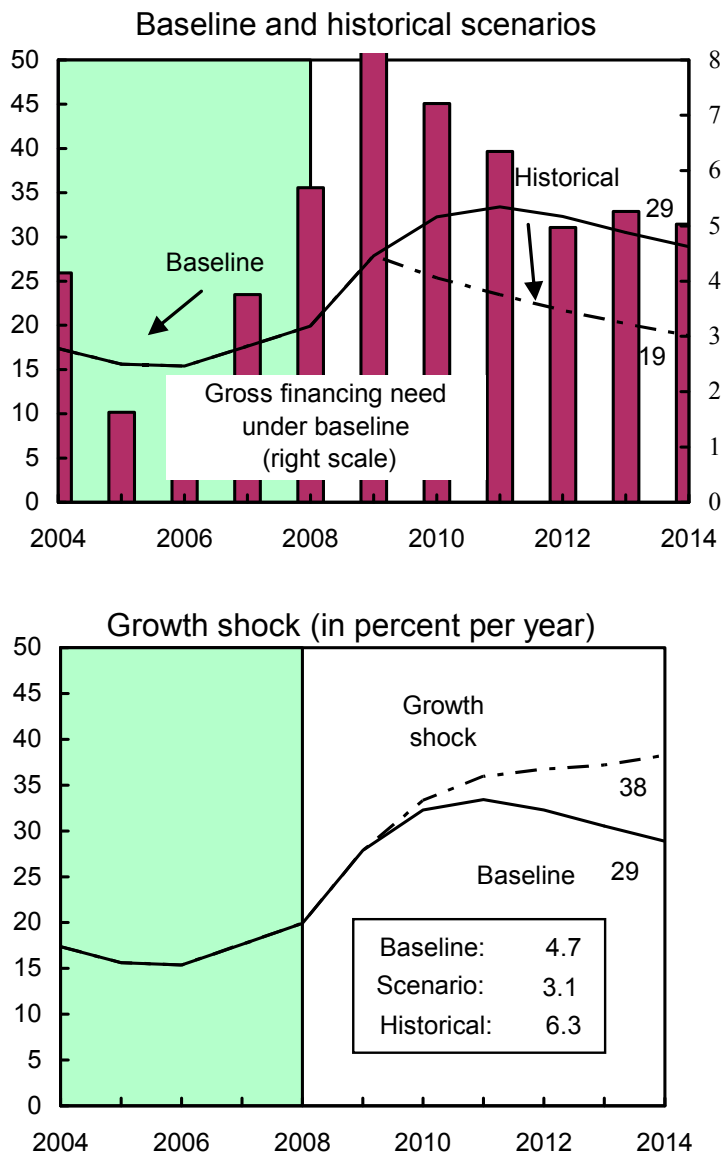

Combined shock 2/

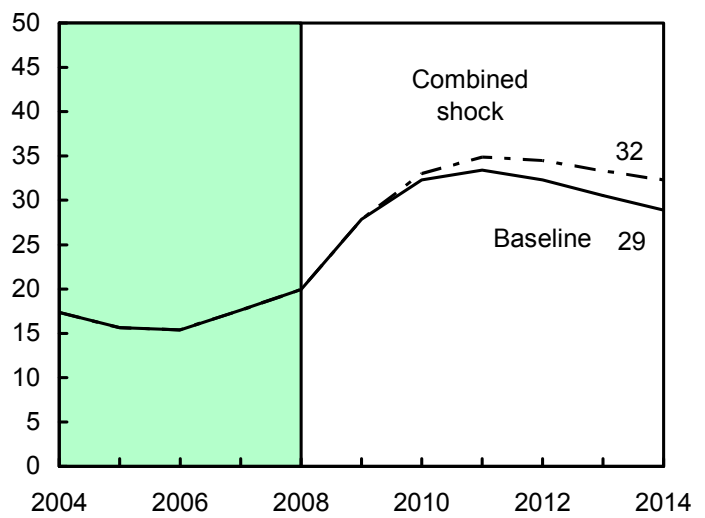

Interest rate shock (in percent)

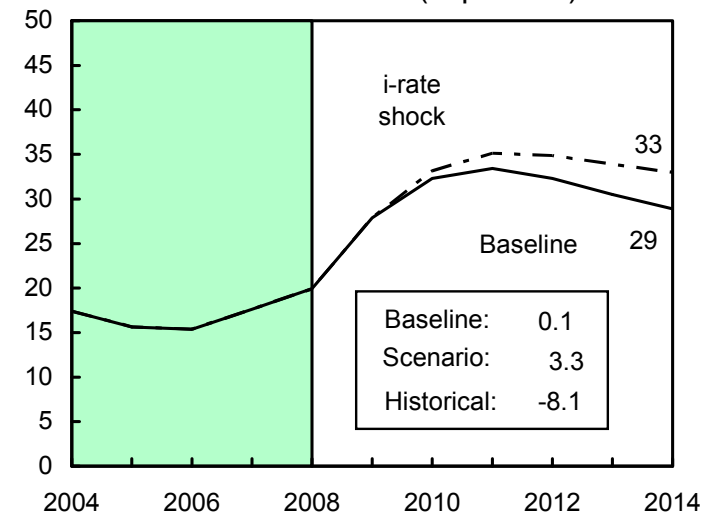

Primary balance shock (in percent of GDP) and no policy change scenario (constant primary balance)

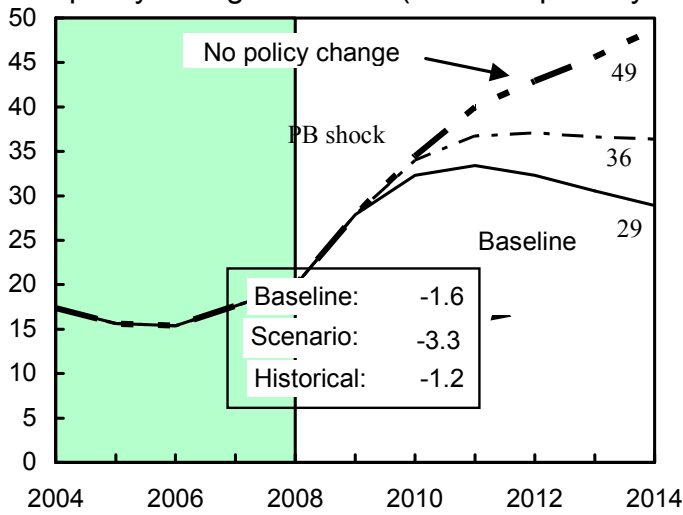

Real depreciation shock 3/

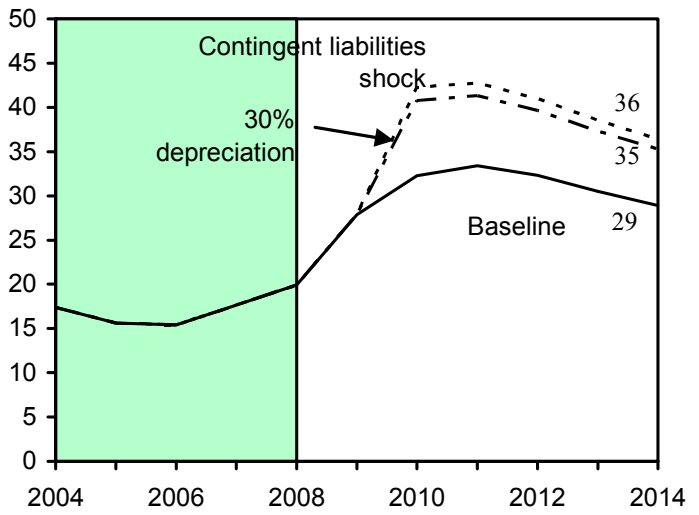

Sources: International Monetary Fund, country desk data, and staff estimates.

$1 /$ Shaded areas represent actual data. Individual shocks are permanent one standard deviation shocks. Figures in the boxes represent average projections for the respective variables in the baseline and scenario being presented. Seven-year historical average for the variable is also shown.

2/ Permanent $1 / 4$ standard deviation shocks applied to real interest rate, growth rate, and primary balance.

3 / One-time real depreciation of 30 percent and 10 percent of GDP shock to contingent liabilities occur in 2009, with real depreciation defined as nominal depreciation (measured by percentage fall in dollar value of local currency) minus domestic inflation (based on GDP deflator). 
Figure 5. Romania: External Debt Sustainability: Bound Tests 1/

(External debt in percent of GDP)
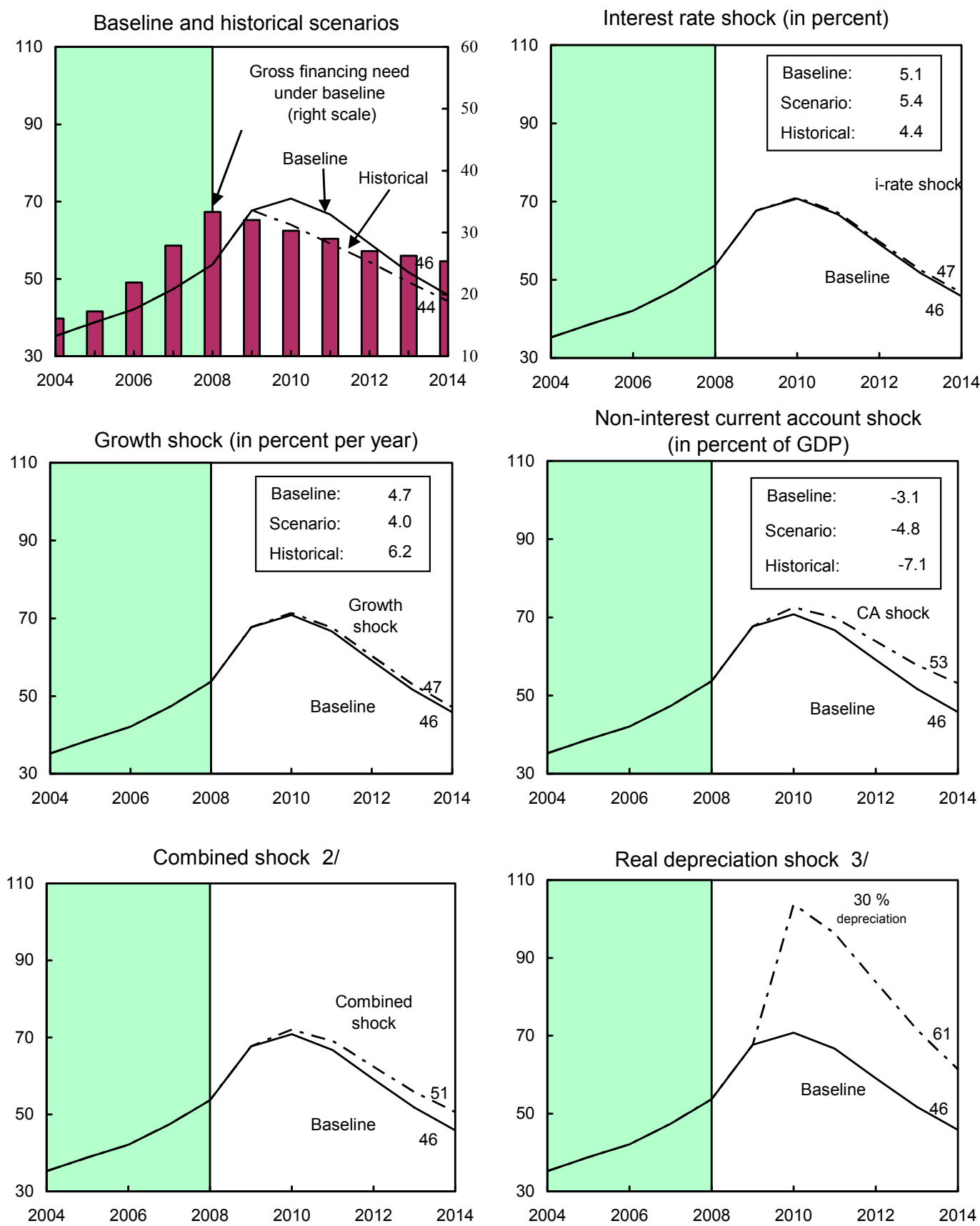

Sources: International Monetary Fund, Country desk data, and staff estimates.

1/ Shaded areas represent actual data. Individual shocks are permanent one-half standard deviation shocks. Figures in the boxes represent average projections for the respective variables in the baseline and scenario being presented. Ten-year historical average for the variable is also shown.

2/ Permanent 1/4 standard deviation shocks applied to real interest rate, growth rate, and current account balance.

3/ One-time real depreciation of 30 percent occurs in 2009. 
Table 1. Romania: Quantitative Program Targets

\begin{tabular}{|c|c|c|c|c|c|c|c|c|}
\hline & \multirow{3}{*}{$\begin{array}{c}2008 \\
\text { Dec } \\
\text { Actual } \\
\end{array}$} & \multicolumn{6}{|c|}{2009} & \multirow{3}{*}{$\begin{array}{c}2010 \\
\text { Dec } \\
\text { Proj } \\
\end{array}$} \\
\hline & & \multirow{2}{*}{$\begin{array}{l}\text { March } \\
\text { Actual }\end{array}$} & \multicolumn{2}{|c|}{ June } & \multicolumn{2}{|c|}{ Sept } & \multirow{2}{*}{$\begin{array}{c}\text { Dec } \\
\text { Prog } \\
\end{array}$} & \\
\hline & & & Prog & Actual & Prog & Revised & & \\
\hline \multicolumn{9}{|l|}{ I. Quantitative Performance Criteria } \\
\hline 1. Cumulative change in net foreign assets ( $\mathrm{mln}$ euros) $1 /$ & 25,532 & $-3,500$ & $-7,600$ & $-5,119$ & $-8,720$ & $-8,720$ & $-9,000$ & -500 \\
\hline 2. Cumulative floor on general government overall balance ( $\mathrm{mln}$ lei) $2 /$ & $-24,655$ & $-8,300$ & $-14,508$ & $-14,456$ & $-18,612$ & $-26,900$ & $-36,500$ & $-31,200$ \\
\hline 3. Cumulative change in general government arrears (bn lei) $1 /$ & 1.06 & 0.35 & 0.0 & 0.49 & 0.0 & 0.0 & -0.15 & -0.91 \\
\hline 4. Ceiling on general government guarantees issued during the year (face value, bn lei) & 0.0 & $\ldots$ & 6.0 & 0.02 & 6.0 & 7.7 & 7.7 & 8.6 \\
\hline \multicolumn{9}{|l|}{ II. Continuous Performance Criterion } \\
\hline 5. Nonaccumulation of external debt arrears & 0 & 0 & 0 & $\ldots$ & 0 & 0 & 0 & 0 \\
\hline \multicolumn{9}{|l|}{ III. Inflation Consultation } \\
\hline \multicolumn{9}{|l|}{ 6. 12-month rate of inflation in consumer prices } \\
\hline Outer band (upper limit) & 8.3 & 8.7 & 8.4 & $\ldots$ & 7.7 & 7.7 & 6.5 & 4.5 \\
\hline Inner band (upper limit) & 7.3 & 7.7 & 7.4 & $\ldots$ & 6.7 & 6.7 & 5.5 & 3.5 \\
\hline Center point & 6.3 & 6.7 & 6.4 & 5.9 & 5.7 & 5.7 & 4.5 & 2.5 \\
\hline Inner band (lower limit) & 5.3 & 5.7 & 5.4 & $\ldots$ & 4.7 & 4.7 & 3.5 & 1.5 \\
\hline Outer band (lower limit) & 4.3 & 4.7 & 4.4 & $\cdots$ & 3.7 & 3.7 & 2.5 & 0.5 \\
\hline \multicolumn{9}{|l|}{ IV. Indicative Target } \\
\hline 7. General government primary spending (excl. EU funds; mln lei) 2/ & 182,411 & 43,900 & 87,505 & 87,271 & 132,356 & & & \\
\hline 8. General government current primary spending (excl. EU funds and social assistance, mln lei) 2/ & 92,327 & 22,149 & & 43,238 & & 63,725 & 81,015 & 79,604 \\
\hline
\end{tabular}

1/ The December 2008 figure is a stock.

2/ The December 2008 figure is for the whole year. 
Table 2. Romania: Structural Conditionality for the Program

\begin{tabular}{|c|c|c|c|}
\hline Measure & Conditionality $1 /$ & Timing & Comments \\
\hline \multicolumn{4}{|l|}{ Fiscal policy } \\
\hline Approval of agreed measures for 2009, including revised 2009 budget (as described in LOI円8) & Prior action & & \\
\hline Ratification by parliament of fiscal measures equivalent to 1.1 percent of GDP & SB & August 31, 2009 & Met in April 2009 \\
\hline Passage of revised public compensation legislation (as described in LOI $\mid 12$, and in $\$ 16$ of the April 24, 2009 LOI) & SB & October 30, 2009 & \\
\hline $\begin{array}{l}\text { Presentation of fiscal responsibility legislation and implementation plan to parliament ( } \$ 14 \text { of the April 24, } 2009 \\
\text { LOI) }\end{array}$ & SB & November 30, 2009 & \\
\hline Passage of revised pension legislation (as described in LOIף13, and in $\llbracket 17$ of the April 24, 2009 LOI) & SB & December 31, 2009 & \\
\hline Approval of agreed 2010 budget (as described in LOI 110 ) & SB & December 31, 2009 & New conditionality \\
\hline $\begin{array}{l}\text { Approval of legislation and internal regulations necessary to implement tax administration reforms (as discussed } \\
\text { in LOIT17) }\end{array}$ & SB & March 31, 2010 & New conditionality \\
\hline Approval of institutional reforms measures to mitigate fiscal risks from local governments and SOEs (LOIT15-16) & SB & June 30, 2010 & New conditionality \\
\hline \multicolumn{4}{|l|}{ Financial Sector } \\
\hline $\begin{array}{l}\text { Passage of amendments to the banking law to strengthen NBR's power to request bank shareholders an } \\
\text { increase in their share capital and limit profit distribution ( }(222 \text { of the April } 24,2009 \text { LOI) }\end{array}$ & SB & June 30, 2009 & Met \\
\hline $\begin{array}{l}\text { Passage of amendments to deposit insurance legislation to broaden grounds for activation of deposit insurance, } \\
\text { expedite payouts and provide a line of credit from the government ( } \mathbb{|} 23 \text { of the April } 24,2009 \text { LOI) }\end{array}$ & SB & August 30, 2009 & Met \\
\hline $\begin{array}{l}\text { Passage of amendments to the banking and winding-up laws to enhance the bank resolution framework, in } \\
\text { consultation with the IMF ( } \$ 22 \text { of the April } 24,2009 \text { LOI) }\end{array}$ & SB & November 30, 2009 & $\begin{array}{l}\text { Moved to March 31, } \\
2010\end{array}$ \\
\hline $\begin{array}{l}\text { Passage of amendments to the banking and winding-up laws to enhance the bank resolution framework, in } \\
\text { consultation with the IMF }\end{array}$ & SB & March 31, 2010 & \\
\hline
\end{tabular}

$1 / \mathrm{SB}=$ structural benchmark. 
Table 3. Romania: Selected Economic and Social Indicators, 2005-11

\begin{tabular}{|c|c|c|c|c|c|c|c|c|}
\hline & \multirow[t]{2}{*}{2005} & \multirow[t]{2}{*}{2006} & \multirow[t]{2}{*}{2007} & \multirow[t]{2}{*}{2008} & \multicolumn{2}{|c|}{2009} & \multirow{2}{*}{$\begin{array}{r}2010 \\
\text { Proj. }\end{array}$} & \multirow{2}{*}{$\begin{array}{r}2011 \\
\text { Proj }\end{array}$} \\
\hline & & & & & Prog. & Prog. & & \\
\hline Output and prices & \multicolumn{8}{|c|}{ (Annual percentage change) } \\
\hline Real GDP & 4.1 & 7.9 & 6.2 & 7.1 & -4.1 & -8.5 & 0.5 & 4.6 \\
\hline Domestic demand & 8.3 & 12.8 & 14.3 & 8.9 & -8.2 & -13.4 & 1.4 & 3.8 \\
\hline Net exports (contribution) & -6.1 & -10.2 & -16.6 & -6.3 & 7.8 & 10.6 & -1.3 & -0.3 \\
\hline Consumer price index (CPI, average) & 9.0 & 6.6 & 4.8 & 7.8 & 5.9 & 5.5 & 3.6 & 3.1 \\
\hline Consumer price index ( $\mathrm{CPI}$, end of period) & 8.6 & 4.9 & 6.6 & 6.3 & 4.5 & 4.3 & 3.0 & 3.2 \\
\hline Unemployment rate & 5.8 & 5.4 & 4.3 & 4.0 & 8.9 & 9.6 & 10.0 & 8.3 \\
\hline Nominal wages & 17.0 & 18.9 & 22.6 & 23.6 & 5.9 & 2.0 & 3.8 & 4.9 \\
\hline \multicolumn{4}{|l|}{ Saving and Investment } & \multicolumn{3}{|c|}{ (In percent of GDP) } & & \\
\hline Gross domestic investment & 23.3 & 26.5 & 31.1 & 31.4 & 30.8 & 30.6 & 29.7 & 30.0 \\
\hline Gross national savings & 14.7 & 16.1 & 17.6 & 19.0 & 23.2 & 25.1 & 24.0 & 24.0 \\
\hline \multicolumn{9}{|l|}{ General government finances } \\
\hline Revenue & 31.4 & 32.3 & 32.5 & 32.8 & 33.0 & 31.6 & 31.7 & 31.6 \\
\hline Expenditure & 32.1 & 33.7 & 35.6 & 37.8 & 37.5 & 39.0 & 37.7 & 35.7 \\
\hline Fiscal balance & -0.7 & -1.4 & -3.1 & -4.9 & -4.6 & -7.3 & -5.9 & -4.2 \\
\hline Privatization proceeds & 1.3 & 0.4 & 0.1 & 0.1 & 0.0 & 0.0 & 0.0 & 0.0 \\
\hline External financing & 0.5 & 0.2 & 0.1 & 0.5 & 2.8 & 4.4 & 2.1 & 0.2 \\
\hline Domestic financing & -1.1 & 0.7 & 2.9 & 4.4 & 1.8 & 2.9 & 3.8 & 4.0 \\
\hline Structural fiscal balance 1/ & -0.6 & -2.1 & -4.3 & -6.6 & -3.8 & -4.7 & -2.3 & -1.1 \\
\hline Gross public debt (direct debt only) & 15.6 & 15.4 & 17.6 & 19.9 & 23.6 & 27.9 & 32.3 & 33.4 \\
\hline Money and credit & \multicolumn{8}{|c|}{ (Annual percentage change) } \\
\hline Broad money (M3) & 36.5 & 28.1 & 33.7 & 17.5 & 6.6 & 4.0 & 5.6 & 6.8 \\
\hline Credit to private sector & - & 54.5 & 60.4 & 33.7 & 16.4 & -1.7 & 5.6 & 13.2 \\
\hline Interest rates, eop & \multicolumn{8}{|c|}{ (In percent) } \\
\hline Euribor, six-months & 2.79 & 3.23 & 4.79 & 3.52 & - & - & - & - \\
\hline NBR policy rate & 7.50 & 8.75 & 7.50 & 10.25 & - & - & - & - \\
\hline NBR lending rate (Lombard) & 14.00 & 14.00 & 12.00 & 14.25 & - & - & - & - \\
\hline Interbank offer rate (1 week) & 7.00 & 7.42 & 7.81 & 13.90 & - & - & - & - \\
\hline Balance of payments & & & & percen & of GDP) & & & \\
\hline Current account balance & -8.6 & -10.4 & -13.5 & -12.4 & -7.5 & -5.5 & -5.7 & -6.0 \\
\hline Merchandise trade balance & -9.8 & -12.0 & -14.4 & -13.4 & -7.1 & -6.7 & -7.3 & -7.1 \\
\hline Capital and financial account balance & 14.9 & 15.5 & 17.5 & 13.4 & -2.3 & 1.0 & 3.1 & 6.6 \\
\hline Foreign direct investment balance & 6.6 & 8.9 & 5.7 & 6.8 & 2.9 & 4.3 & 4.5 & 4.5 \\
\hline International investment position & -29.2 & -35.3 & -40.2 & -52.9 & -55.6 & -57.9 & -56.3 & -56.0 \\
\hline Gross official reserves & 22.9 & 23.2 & 23.2 & 21.4 & 24.6 & 28.6 & 31.6 & 30.2 \\
\hline Gross external debt & 38.8 & 42.1 & 47.3 & 53.7 & 64.2 & 67.7 & 70.8 & 66.7 \\
\hline \multicolumn{9}{|l|}{ Exchange rates } \\
\hline Lei per euro (end of period) & 3.7 & 3.4 & 3.5 & 4.0 & - & - & - & - \\
\hline Lei per euro (average) & 3.6 & 3.5 & 3.3 & 3.7 & - & - & - & - \\
\hline \multicolumn{9}{|l|}{ Real effective exchange rate } \\
\hline CPI based (depreciation -) & 18.0 & 7.6 & 9.0 & -4.2 & - & - & - & - \\
\hline \multicolumn{9}{|l|}{ Memorandum Items: } \\
\hline Nominal GDP (in bn RON) & 289.0 & 344.7 & 412.8 & 504.0 & 531.3 & 497.4 & 525.2 & 579.8 \\
\hline \multicolumn{9}{|c|}{$\begin{array}{l}\text { Social Indicators (reference year in parentheses) } \\
\text { Per capita GNI (Atlas method, 2005): US } \$ 4445 \text {; Income distribution (GINI index, 2000): 30.3; Poverty rate (2005): } 13 \text { p.c.; } \\
\text { Primary education completion rate (2004): } 94 \text { percent; Gender pay gap (2003): } 18 \text { percent; } \\
\text { Life expectancy at birth (2004): } 71.3 \text {; Infant mortality per } 1000 \text { live births (2004): } 16.8 \text {. }\end{array}$} \\
\hline
\end{tabular}

Sources: Romanian authorities; Fund staff estimates and projections; and World Development Indicators database.

1/ Actual fiscal balance adjusted for the automatic effects of the business cycle. 
Table 4. Romania: Balance of Payments, 2005-11 (In billions of euros, unless otherwise indicated)

\begin{tabular}{|c|c|c|c|c|c|c|c|c|}
\hline & \multirow[t]{2}{*}{2005} & \multirow[t]{2}{*}{2006} & \multirow[t]{2}{*}{2007} & \multirow[t]{2}{*}{2008} & \multicolumn{2}{|c|}{2009} & \multirow{2}{*}{$\begin{array}{r}2010 \\
\text { Proj. }\end{array}$} & \multirow{2}{*}{$\begin{array}{r}2011 \\
\text { Proj. }\end{array}$} \\
\hline & & & & & Prog. $\mathrm{F}$ & $\overline{\text { Rev.prog. }}$ & & \\
\hline Current account balance & -6.9 & -10.2 & -16.7 & -16.9 & -9.0 & -6.5 & -6.8 & -7.9 \\
\hline Merchandise trade balance & -7.8 & -11.8 & -17.8 & -18.4 & -8.6 & -7.9 & -8.7 & -9.3 \\
\hline Exports (f.o.b.) & 22.3 & 25.9 & 29.5 & 33.6 & 30.5 & 28.6 & 29.9 & 31.3 \\
\hline Imports (f.o.b.) & -30.1 & -37.6 & -47.4 & -52.0 & -39.1 & -36.5 & -38.6 & -40.6 \\
\hline Services balance & -0.3 & 0.0 & 0.5 & 0.8 & 1.6 & 0.2 & 0.3 & 0.4 \\
\hline Exports of non-factor services & 4.1 & 5.6 & 6.9 & 8.8 & 8.6 & 6.7 & 7.0 & 7.4 \\
\hline Imports of non-factor services & -4.4 & -5.6 & -6.5 & -7.9 & -7.0 & -6.5 & -6.8 & -7.0 \\
\hline Income balance & -2.3 & -3.2 & -4.2 & -5.4 & -6.7 & -3.5 & -3.3 & -4.3 \\
\hline Receipts & 1.2 & 1.7 & 2.4 & 2.3 & 2.0 & 1.2 & 1.4 & 1.8 \\
\hline Payments & -3.6 & -5.0 & -6.6 & -7.6 & -8.7 & -4.7 & -4.8 & -6.1 \\
\hline Current transfer balance & 3.6 & 4.8 & 4.8 & 6.0 & 4.7 & 4.7 & 5.0 & 5.3 \\
\hline Capital and financial account balance & 12.1 & 14.8 & 21.9 & 18.3 & -2.7 & 1.2 & 3.8 & 8.7 \\
\hline Capital transfer balance & 0.6 & 0.0 & 0.8 & 0.6 & 2.7 & 0.8 & 0.7 & 0.6 \\
\hline Foreign direct investment balance & 5.2 & 8.7 & 7.0 & 9.3 & 3.5 & 5.0 & 5.4 & 5.9 \\
\hline Portfolio investment balance & 0.3 & -0.4 & 0.4 & -1.2 & -0.8 & -0.4 & -0.2 & 0.5 \\
\hline Other investment balance & 6.0 & 6.5 & 13.6 & 9.6 & -8.1 & -4.2 & -2.1 & 1.6 \\
\hline General government 1/ & 0.6 & -0.1 & -0.6 & 0.6 & -0.3 & 1.9 & -0.5 & 0.0 \\
\hline Domestic banks & 2.6 & 3.7 & 6.0 & 3.3 & -1.1 & -2.4 & 0.0 & 0.0 \\
\hline Other private sector & 2.8 & 2.8 & 8.3 & 5.8 & -6.7 & -3.7 & -1.7 & 1.6 \\
\hline Errors and omissions & 0.4 & 0.6 & -0.6 & -0.8 & 0.0 & 0.0 & 0.0 & 0.0 \\
\hline Prospective financing & $\ldots$ & $\ldots$ & $\ldots$ & $\ldots$ & 3.3 & 3.1 & 3.8 & 0.2 \\
\hline European Commission & $\ldots$ & $\ldots$ & $\ldots$ & $\ldots$ & 2.5 & 2.5 & 2.4 & 0.2 \\
\hline World Bank & $\ldots$ & $\ldots$ & $\ldots$ & $\ldots$ & 0.5 & 0.3 & 0.7 & 0.0 \\
\hline EIB/EBRD & $\ldots$ & $\ldots$ & $\ldots$ & $\ldots$ & 0.3 & 0.3 & 0.7 & 0.0 \\
\hline Overall balance & 5.6 & 5.3 & 4.6 & 0.6 & -8.5 & -2.2 & 0.7 & 0.9 \\
\hline Financing & -5.6 & -5.3 & -4.6 & -0.6 & 8.5 & 2.2 & -0.7 & -0.9 \\
\hline Gross international reserves (increase: -) & -5.4 & -5.2 & -4.5 & -0.6 & 0.0 & -4.5 & -4.1 & -1.8 \\
\hline Use of Fund credit, net & -0.1 & -0.1 & -0.1 & 0.0 & 8.5 & 6.7 & 3.4 & 1.0 \\
\hline Purchases 2/ & 0.0 & 0.0 & 0.0 & 0.0 & 8.5 & 6.7 & 3.4 & 1.0 \\
\hline Repurchases & 0.1 & 0.1 & 0.1 & 0.0 & 0.0 & 0.0 & 0.0 & 0.0 \\
\hline Other liabilities, net & -0.1 & 0.0 & 0.0 & 0.0 & 0.0 & 0.0 & 0.0 & 0.0 \\
\hline Memorandum items: & \multicolumn{8}{|c|}{ (In percent of GDP) } \\
\hline Current account balance & -8.6 & -10.4 & -13.5 & -12.4 & -7.5 & -5.5 & -5.7 & -6.0 \\
\hline Foreign direct investment balance & 6.6 & 8.9 & 5.7 & 6.8 & 2.9 & 4.3 & 4.5 & 4.5 \\
\hline Merchandise trade balance & -9.8 & -12.0 & -14.4 & -13.4 & -7.1 & -6.7 & -7.3 & -7.1 \\
\hline Exports & 27.9 & 26.4 & 23.9 & 24.6 & 25.5 & 24.3 & 25.0 & 23.8 \\
\hline Imports & -37.7 & -38.4 & -38.3 & -38.0 & -32.6 & -31.0 & -32.2 & -30.9 \\
\hline Gross external financing requirement & 16.3 & 20.0 & 26.9 & 33.8 & 35.1 & 32.0 & 31.1 & 29.9 \\
\hline & \multicolumn{8}{|c|}{ (Annual percentage change) } \\
\hline Terms of trade (merchandise) & 2.8 & 6.4 & 5.3 & -3.2 & 8.4 & 8.1 & -0.7 & -1.6 \\
\hline Merchandise export volume & 6.1 & 6.8 & 8.7 & 10.4 & -7.0 & -13.0 & 3.0 & 3.7 \\
\hline Merchandise import volume & 15.0 & 22.3 & 26.1 & 3.5 & -15.2 & -21.6 & 3.5 & 2.6 \\
\hline Merchandise export prices & 9.6 & 8.5 & 5.2 & 3.1 & -2.4 & -2.1 & 1.4 & 1.0 \\
\hline \multirow[t]{2}{*}{ Merchandise import prices } & 7.0 & 2.2 & -0.1 & 6.1 & -11.1 & -10.5 & 2.1 & 2.6 \\
\hline & \multicolumn{8}{|c|}{ (In billions of euros) } \\
\hline Gross international reserves 3/ & 18.1 & 22.7 & 28.7 & 29.2 & 29.4 & 33.7 & 37.8 & 39.6 \\
\hline GDP & 79.7 & 97.8 & 123.6 & 136.8 & 119.7 & 117.7 & 119.7 & 131.3 \\
\hline
\end{tabular}

Sources: Romanian authorities; and Fund staff estimates and projections.

1/ For 2009, projections include IMF disbursement to the Treasury amounting to $€ 1.7$ billion, and a projected issuance of an Euro bond of $€ 0.5$ billion, both in the second half of the year. These inflows were not included in the original program projections. 2/ For 2009, total IMF disbursement is projected to amount to $€ 8.4$ billion, of which $€ 1.7$ will be disbursed directly to the Treasury, and included in the capital and financial account as noted in footnote 1.

3/ Does not include the allocation of SDR 908.8 million (about $€ 990$ million) that was made avaialable to Romania on August 28, 2009 pending agreement on the statistical treatment of this allocation in foreign assets and liabilities. 
Table 5. Romania: Gross Financing Requirements, 2009-11 (In billions of euros, unless otherwise indicated)

\begin{tabular}{|c|c|c|c|c|c|c|c|c|c|c|c|}
\hline & \multicolumn{8}{|c|}{2009} & \multirow{3}{*}{$\begin{array}{l}2010 \\
\text { Proj. }\end{array}$} & \multirow{3}{*}{$\begin{array}{l}2011 \\
\text { Proj. }\end{array}$} & \multirow{3}{*}{$\begin{array}{c}\text { Total } \\
2009-11\end{array}$} \\
\hline & \multicolumn{2}{|c|}{ Q1 } & \multicolumn{2}{|c|}{ Q2 } & \multirow{2}{*}{$\begin{array}{c}\text { Q3 } \\
\text { Proj. }\end{array}$} & \multirow{2}{*}{$\begin{array}{c}\text { Q4 } \\
\text { Proj. }\end{array}$} & \multicolumn{2}{|c|}{ Year } & & & \\
\hline & Prog & Act & Prog & Prel & & & Prog & Rev.prog. & & & \\
\hline I. Total financing requirements & 11.7 & 11.5 & 10.1 & 14.3 & 7.3 & 8.8 & 43.9 & 41.5 & 42.8 & 43.2 & 127.5 \\
\hline I.A. Current account deficit & 1.5 & 0.7 & 2.7 & 1.7 & 2.0 & 2.1 & 9.0 & 6.5 & 6.9 & 7.9 & 21.3 \\
\hline I.B. Short-term debt & 8.4 & 8.4 & 4.3 & 9.3 & 3.5 & 3.5 & 22.5 & 24.7 & 20.7 & 20.7 & 66.1 \\
\hline Public sector & 0.1 & 2.8 & 0.1 & 4.1 & 0.0 & 0.0 & 0.3 & 6.9 & 7.1 & 7.1 & 21.1 \\
\hline Banks & 5.5 & 3.6 & 1.4 & 4.5 & 1.7 & 1.7 & 10.6 & 11.5 & 8.8 & 8.8 & 29.0 \\
\hline Corporates & 2.9 & 2.0 & 2.7 & 0.7 & 1.8 & 1.8 & 11.6 & 6.3 & 4.9 & 4.9 & 16.0 \\
\hline I.C. Maturing medium- and long-term debt & 1.3 & 1.5 & 2.0 & 2.6 & 1.2 & 2.8 & 9.3 & 8.2 & 13.3 & 14.6 & 36.1 \\
\hline Public sector & 0.2 & 0.2 & 0.3 & 0.3 & 0.2 & 0.3 & 1.0 & 1.0 & 2.8 & 3.3 & 7.1 \\
\hline Banks & 0.1 & 0.8 & 0.2 & 1.6 & 0.5 & 1.1 & 1.8 & 4.0 & 6.0 & 6.4 & 16.4 \\
\hline Corporates & 1.0 & 0.5 & 1.6 & 0.7 & 0.5 & 1.4 & 6.5 & 3.1 & 4.6 & 4.9 & 12.6 \\
\hline I.D. Other net capital outflows $1 /$ & 0.5 & 0.9 & 1.1 & 0.7 & 0.6 & 0.4 & 3.1 & 2.2 & 1.9 & 0.0 & 4.1 \\
\hline II. Total financing sources & 9.2 & 9.6 & 6.3 & 11.2 & 6.4 & 7.4 & 32.2 & 34.5 & 39.7 & 43.5 & 117.7 \\
\hline II.A. Foreign direct investment, net & 1.2 & 1.5 & 0.9 & 1.4 & 1.1 & 1.0 & 3.5 & 5.0 & 5.4 & 5.9 & 16.3 \\
\hline II.B. Capital account inflows (EU) & 0.3 & 0.0 & 0.7 & 0.0 & 0.3 & 0.5 & 2.7 & 0.8 & 0.7 & 0.6 & 2.2 \\
\hline II.C. Short-term debt & 6.8 & 6.8 & 3.2 & 7.2 & 3.4 & 3.4 & 18.6 & 20.7 & 20.7 & 20.7 & 62.2 \\
\hline Public sector & 0.1 & 3.7 & 0.1 & 3.0 & 0.2 & 0.2 & 0.3 & 7.1 & 7.1 & 7.1 & 21.3 \\
\hline Banks & 4.8 & 2.4 & 1.3 & 3.3 & 1.5 & 1.5 & 9.6 & 8.8 & 8.8 & 8.8 & 26.3 \\
\hline Corporates & 2.0 & 0.7 & 1.9 & 0.9 & 1.6 & 1.6 & 8.7 & 4.9 & 4.9 & 4.9 & 14.6 \\
\hline II.D. Medium- and long-term debt & 0.9 & 1.3 & 1.5 & 2.6 & 1.6 & 2.4 & 7.4 & 8.0 & 12.9 & 16.2 & 37.1 \\
\hline Public sector $2 /$ & 0.1 & 0.0 & 0.2 & 0.2 & 0.7 & 0.1 & 0.7 & 1.1 & 2.3 & 3.3 & 6.7 \\
\hline Banks & 0.1 & 0.8 & 0.2 & 2.0 & 0.5 & 1.0 & 1.7 & 4.3 & 6.0 & 6.4 & 16.6 \\
\hline Corporates & 0.7 & 0.5 & 1.1 & 0.4 & 0.5 & 1.3 & 5.0 & 2.6 & 4.6 & 6.5 & 13.7 \\
\hline III. Increase in gross reserves & -3.0 & -1.7 & 1.1 & 1.8 & 2.9 & 1.3 & 0.0 & 4.5 & 4.0 & 1.4 & 9.9 \\
\hline IV. Errors and omissions & 0.0 & 0.2 & 0.0 & -0.1 & 0.0 & 0.0 & 11.8 & 0.0 & 0.0 & 0.0 & 0.0 \\
\hline V. Program financing & 0.0 & 0.0 & 5.0 & 4.9 & 3.8 & 2.8 & 11.8 & 11.5 & 7.1 & 1.1 & 19.8 \\
\hline IMF & 0.0 & 0.0 & 5.0 & 4.9 & 1.9 & 1.6 & 8.5 & 8.4 & 3.4 & 1.0 & 12.8 \\
\hline Others & 0.0 & 0.0 & 0.0 & 0.0 & 1.9 & 1.2 & 3.3 & 3.1 & 3.8 & 0.2 & 7.0 \\
\hline European Commission & 0.0 & 0.0 & 0.0 & 0.0 & 1.50 & 1.00 & 2.50 & 2.50 & 2.35 & 0.15 & 5.0 \\
\hline World Bank & 0.0 & 0.0 & 0.0 & 0.0 & 0.3 & 0.0 & 0.5 & 0.3 & 0.7 & 0.0 & 1.0 \\
\hline EIB/EBRD & 0.0 & 0.0 & 0.0 & 0.0 & 0.1 & 0.2 & 0.3 & 0.3 & 0.7 & 0.0 & 1.0 \\
\hline \multicolumn{12}{|l|}{ Memorandum items: } \\
\hline Banks & 87 & 72 & 87 & 87 & 92 & 92 & 91 & 84 & 100 & 100 & $\ldots$ \\
\hline Corporates & 69 & 48 & 69 & 93 & 90 & 90 & 76 & 79 & 100 & 100 & $\ldots$ \\
\hline Gross international reserves & 26.4 & 27.7 & 27.5 & 29.5 & 32.4 & 33.9 & 29.4 & 33.9 & 38.0 & 39.8 & $\ldots$ \\
\hline Coverage of gross international reserves & & & & & & & & & & & \\
\hline - Months of imports of GFNS (next year) & & 8.5 & & 8.6 & & & 7 & 9.0 & 9.6 & 9.1 & $\ldots$ \\
\hline - Share of short-term external debt (in percent) & 83 & 92 & 85 & 106 & 116 & 122 & 93 & 122 & 136 & 143 & $\ldots$ \\
\hline
\end{tabular}

Source: IMF staff estimates.

$1 /$ Includes includes portfolio equity, financial derivatives and other investments, assets position

2/ Excludes the disbursements by the IMF directly to the Treasury, amounting to $€ 0.9$ billion in 2009Q3 and $€ 0.8$ billion in 2009 Q4. 
Table 6. Romania: General Government Operations, 2005-11 (In percent of GDP)

\begin{tabular}{|c|c|c|c|c|c|c|c|c|c|c|}
\hline & \multirow[t]{2}{*}{2005} & \multirow[t]{2}{*}{2006} & \multirow[t]{2}{*}{2007} & \multirow[t]{2}{*}{2008} & \multicolumn{3}{|c|}{2009} & \multicolumn{2}{|c|}{2010} & \multirow{2}{*}{$\begin{array}{l}2011 \\
\text { Proj. }\end{array}$} \\
\hline & & & & & Prog. & Proj. & Rev. prog. & Proj. & Rev. prog. & \\
\hline Revenue & 31.4 & 32.3 & 32.5 & 32.8 & 33.0 & 31.7 & 31.6 & 31.4 & 31.7 & 31.6 \\
\hline Taxes & 27.3 & 28.2 & 28.1 & 28.5 & 28.1 & 27.5 & 27.5 & 27.4 & 27.8 & 27.6 \\
\hline Taxes on profits & 2.7 & 2.7 & 2.9 & 2.9 & 2.6 & 2.6 & 2.6 & 2.6 & 2.6 & 2.6 \\
\hline Taxes on income & 2.4 & 2.8 & 3.5 & 3.7 & 3.5 & 3.8 & 3.8 & 3.7 & 3.7 & 3.7 \\
\hline Value-added taxes & 7.8 & 8.1 & 7.6 & 8.1 & 7.4 & 6.9 & 7.0 & 7.0 & 7.0 & 7.1 \\
\hline Excises & 3.1 & 3.1 & 3.0 & 2.7 & 2.9 & 2.9 & 2.9 & 3.0 & 3.2 & 3.2 \\
\hline Customs duties & 0.8 & 0.8 & 0.2 & 0.2 & 0.1 & 0.1 & 0.1 & 0.1 & 0.1 & 0.1 \\
\hline Social security contributions & 9.5 & 9.6 & 9.6 & 9.7 & 10.3 & 9.9 & 9.8 & 9.7 & 9.8 & 9.6 \\
\hline Other taxes & 1.1 & 1.2 & 1.4 & 1.3 & 1.3 & 1.3 & 1.3 & 1.3 & 1.4 & 1.4 \\
\hline Nontax revenue & 3.2 & 3.3 & 3.4 & 3.2 & 3.1 & 2.4 & 2.4 & 2.4 & 2.4 & 2.4 \\
\hline Capital revenue & 0.3 & 0.3 & 0.2 & 0.2 & 0.2 & 0.2 & 0.2 & 0.2 & 0.2 & 0.2 \\
\hline Grants, including EU disbursements & 0.6 & 0.5 & 0.8 & 0.9 & 1.6 & 1.7 & 1.6 & 1.4 & 1.4 & 1.4 \\
\hline Financial operations and other & $\cdots$ & $\cdots$ & $\cdots$ & 0.0 & $\ldots$ & $\cdots$ & $\cdots$ & $\ldots$ & $\cdots$ & ... \\
\hline Expenditure & 32.1 & 33.7 & 35.6 & 37.8 & 37.5 & 39.8 & 39.0 & 39.2 & 37.7 & 35.7 \\
\hline Current expenditure & 29.1 & 29.4 & 30.9 & 33.2 & 34.1 & 36.2 & 35.9 & 35.7 & 34.5 & 32.7 \\
\hline Compensation of employees & 7.4 & 8.0 & 8.2 & 9.1 & 7.8 & 8.8 & 9.0 & 8.7 & 8.7 & 8.2 \\
\hline Maintenance and operations & 6.3 & 6.2 & 6.1 & 6.4 & 5.1 & 5.5 & 5.1 & 5.4 & 4.6 & 4.3 \\
\hline Interest & 1.2 & 0.8 & 0.7 & 0.7 & 1.6 & 1.7 & 1.6 & 1.7 & 1.7 & 1.8 \\
\hline Subsidies & 2.2 & 2.2 & 1.7 & 1.6 & 1.2 & 1.2 & 1.3 & 1.1 & 1.1 & 1.0 \\
\hline Transfers 1/ & 12.0 & 12.2 & 14.2 & 15.4 & 17.7 & 18.2 & 18.1 & 18.0 & 17.6 & 16.6 \\
\hline Pensions & 5.8 & 5.4 & 5.5 & 6.6 & 7.4 & 7.9 & 8.0 & 7.9 & 8.0 & 7.6 \\
\hline Other social transfers & 3.7 & 3.6 & 3.9 & 4.2 & 4.4 & 4.7 & 4.8 & 4.6 & 4.4 & 4.0 \\
\hline Other transfers $2 /$ & 2.1 & 2.5 & 4.1 & 3.5 & 5.2 & 4.9 & 4.6 & 4.8 & 4.6 & 4.5 \\
\hline olw contribution to EU budget & $\ldots$ & $\ldots$ & 0.9 & 0.9 & 1.0 & 0.0 & 1.1 & 0.0 & 1.2 & 1.1 \\
\hline olw pre-accession EU funds & $\ldots$ & $\ldots$ & $\ldots$ & $\ldots$ & 0.8 & 0.9 & 0.9 & 0.7 & 0.7 & 0.4 \\
\hline Other spending & 0.4 & 0.8 & 0.7 & 1.2 & 0.7 & 0.7 & 0.7 & 0.7 & 0.6 & 0.5 \\
\hline Proj. with ext. credits & 0.0 & 0.0 & 0.0 & 0.0 & 0.8 & 0.8 & 0.8 & 0.8 & 0.8 & 0.8 \\
\hline Capital expenditure 3/ & 3.0 & 4.3 & 4.8 & 4.7 & 3.5 & 3.5 & 3.3 & 3.5 & 3.1 & 3.0 \\
\hline Reserve fund & 0.0 & 0.0 & 0.0 & 0.0 & 0.0 & 0.1 & 0.2 & 0.1 & 0.1 & 0.1 \\
\hline Net lending & 0.0 & 0.0 & 0.0 & -0.1 & 0.0 & 0.0 & -0.4 & 0.0 & 0.0 & 0.0 \\
\hline Fiscal balance & -0.7 & -1.4 & -3.1 & -4.9 & -4.6 & -8.1 & -7.3 & -7.9 & -5.9 & -4.2 \\
\hline Primary balance & 0.5 & -0.6 & -2.4 & -4.2 & -3.0 & -6.4 & -5.8 & -6.2 & -4.2 & -2.3 \\
\hline Financing & 0.7 & 1.4 & 3.1 & 4.9 & 4.6 & 8.1 & 7.3 & 7.9 & 5.9 & 4.2 \\
\hline Privatization proceeds & 1.3 & 0.4 & 0.1 & 0.1 & 0.0 & 0.0 & 0.0 & 0.0 & 0.0 & 0.0 \\
\hline External & 0.5 & 0.2 & 0.1 & 0.5 & 2.8 & 5.2 & 4.4 & 4.1 & 2.1 & 0.2 \\
\hline Domestic & -1.1 & 0.7 & 2.9 & 4.4 & 1.8 & 2.9 & 2.9 & 3.8 & 3.8 & 4.0 \\
\hline \multicolumn{11}{|l|}{ Financial liabilities } \\
\hline Gross public debt $4 /$ & 20.4 & 18.4 & 19.9 & 21.8 & 25.3 & 30.2 & 29.6 & 35.9 & 33.9 & 34.8 \\
\hline Gross public debt excl. guarantees & 15.6 & 15.4 & 17.6 & 19.9 & 23.6 & 28.5 & 27.9 & 34.3 & 32.3 & 33.4 \\
\hline External & 10.6 & 7.9 & 7.2 & 7.1 & 9.4 & 12.2 & 11.6 & 15.0 & 13.0 & 12.0 \\
\hline Domestic & 5.0 & 7.5 & 10.4 & 12.8 & 14.2 & 16.3 & 16.3 & 19.2 & 19.2 & 21.4 \\
\hline \multicolumn{11}{|l|}{ Memorandum items: } \\
\hline Total capital spending & $\ldots$ & $\ldots$ & $\ldots$ & 6.0 & 5.8 & 6.0 & 5.6 & 5.6 & 5.2 & 5.1 \\
\hline Fiscal balance (ESA95 basis) & -1.4 & -2.2 & -2.5 & -5.3 & $\ldots$ & $\ldots$ & $\ldots$ & $\ldots$ & $\ldots$ & ... \\
\hline Output gap $5 /$ & -0.4 & 2.2 & 3.2 & 4.5 & -2.4 & -6.8 & -6.8 & -9.5 & -9.5 & -8.5 \\
\hline Conventional structural fiscal balance & -0.6 & -2.1 & -4.3 & -6.6 & -3.7 & -5.4 & -4.7 & -4.2 & -2.3 & -1.1 \\
\hline Nominal GDP (in billions of RON) & 289.0 & 344.7 & 412.8 & 504.0 & 531.3 & 497.4 & 497.4 & 525.2 & 525.2 & 579.8 \\
\hline
\end{tabular}

Sources: Ministry of Finance; Eurostat; and Fund staff projections.

$1 /$ Increase in 2009 mostly reflects higher EU-financed capital spending and budgeted rise in pensions.

2/ Includes co-financing of EU projects.

3 / Does not include all capital spending. Total investment increased from 6.0 percent of GDP in 2008 to

7.0 percent of GDP in the authorities' 2009 budget.

4/ Total public debt, including government debt, local government debt, and guarantees.

$5 /$ Percentage deviation of actual from potential GDP.

(continued) 
Table 6. Romania: General Government Operations, 2005-11 (concluded) (In millions of RON)

\begin{tabular}{|c|c|c|c|c|c|c|c|c|c|c|}
\hline & \multirow[t]{2}{*}{2005} & \multirow[t]{2}{*}{2006} & \multirow[t]{2}{*}{2007} & \multirow[t]{2}{*}{2008} & \multicolumn{3}{|c|}{2009} & \multicolumn{2}{|c|}{2010} & \multirow{2}{*}{$\begin{array}{l}2011 \\
\text { Proj. }\end{array}$} \\
\hline & & & & & Prog. & Proj. & Rev. prog. & Proj. & Rev. prog. & \\
\hline Revenue & 90,679 & 111,388 & 134,173 & 165,549 & 175,125 & 157,833 & 157,239 & 164,638 & 166,724 & 183,117 \\
\hline Taxes & 79,016 & 97,155 & 116,066 & 143,855 & 149,267 & 136,871 & 136,827 & 143,941 & 146,028 & 160,268 \\
\hline Taxes on profits & 7,793 & 9,319 & 11,917 & 14,426 & 13,594 & 13,056 & 13,056 & 13,439 & 13,439 & 15,060 \\
\hline Taxes on income & 6,814 & 9,787 & 14,402 & 18,523 & 18,347 & 18,826 & 18,826 & 19,596 & 19,596 & 21,418 \\
\hline Value-added taxes & 22,538 & 27,763 & 31,243 & 40,874 & 39,476 & 34,314 & 34,642 & 36,865 & 36,865 & 41,106 \\
\hline Excises & 9,079 & 10,626 & 12,552 & 13,646 & 15,566 & 14,666 & 14,666 & 15,641 & 16,741 & 18,482 \\
\hline Customs duties & 2,187 & 2,596 & 856 & 962 & 699 & 533 & 533 & 556 & 556 & 587 \\
\hline Social security contributions & 27,476 & 33,021 & 39,443 & 49,008 & 54,831 & 49,171 & 48,798 & 51,186 & 51,646 & 55,683 \\
\hline Other taxes & 3,129 & 4,043 & 5,653 & 6,416 & 6,755 & 6,305 & 6,305 & 6,657 & 7,184 & 7,932 \\
\hline Nontax revenue & 9,232 & 11,457 & 13,991 & 15,892 & 16,622 & 11,895 & 11,895 & 12,560 & 12,560 & 13,866 \\
\hline Capital revenue & 752 & 1,020 & 963 & 1,076 & 965 & 796 & 796 & 841 & 841 & 928 \\
\hline Grants & 1,679 & 1,756 & 3,154 & 4,702 & 8,271 & 8,271 & 7,721 & 7,296 & 7,296 & 8,055 \\
\hline o/w EU pre-accession funds & $\ldots$ & $\ldots$ & $\ldots$ & $\ldots$ & 4,380 & 4,380 & 4,380 & 3,415 & 3,415 & 2,093 \\
\hline Financial operations and other & $\ldots$ & $\ldots$ & $\ldots$ & 25 & $\ldots$ & & $\ldots$ & $\ldots$ & $\ldots$ & $\ldots$ \\
\hline Expenditure & 92,660 & 116,050 & 147,141 & 190,407 & 199,436 & 198,068 & 193,728 & 206,013 & 197,812 & 207,197 \\
\hline Current expenditure & 83,975 & 101,232 & 127,513 & 167,095 & 180,929 & 180,196 & 178,414 & 187,313 & 181,190 & 189,696 \\
\hline Compensation of employees & 21,356 & 27,593 & 33,696 & 45,608 & 43,601 & 43,600 & 44,893 & 45,635 & 45,521 & 47,536 \\
\hline Maintenance and operations & 18,324 & 21,381 & 25,187 & 32,012 & 26,945 & 27,292 & 25,202 & 28,273 & 24,303 & 25,098 \\
\hline Interest & 3,417 & 2,736 & 3,096 & 3,776 & 8,362 & 8,350 & 7,872 & 8,908 & 8,908 & 10,491 \\
\hline Subsidies & 6,321 & 7,429 & 6,875 & 7,899 & 6,118 & 6,118 & 6,650 & 5,985 & 5,985 & 6,027 \\
\hline Transfers $1 /$ & 34,557 & 42,093 & 58,660 & 77,800 & 93,897 & 90,712 & 90,021 & 94,565 & 92,526 & 96,186 \\
\hline Pensions & 16,682 & 18,528 & 22,664 & 33,187 & 39,370 & 39,330 & 39,830 & 41,434 & 41,953 & 43,861 \\
\hline Other social transfers & 10,758 & 12,333 & 16,186 & 20,973 & 23,613 & 23,496 & 23,979 & 24,340 & 23,053 & 23,019 \\
\hline Other transfers $2 /$ & 6,076 & 8,577 & 16,769 & 17,646 & 25,276 & 24,343 & 22,822 & 25,120 & 24,379 & 26,138 \\
\hline olw contribution to EU budget & $\ldots$ & $\ldots$ & 3,799 & 4,506 & 5,528 & 0 & 5,458 & 0 & 6,100 & 6,493 \\
\hline olw pre-accession EU funds & & & & & 4,380 & 4,380 & 4,380 & 3,415 & 3,415 & 2,093 \\
\hline Other spending & 1,041 & 2,656 & 3,041 & 5,993 & 3,516 & 3,543 & 3,391 & 3,670 & 3,141 & 3,167 \\
\hline Proj. with ext. credits & 0 & 0 & 0 & 0 & 4,128 & 4,124 & 3,776 & 3,948 & 3,948 & 4,359 \\
\hline Capital expenditure $3 /$ & 8,685 & 14,817 & 19,629 & 23,794 & 18,339 & 17,427 & 16,194 & 18,399 & 16,322 & 17,170 \\
\hline Reserve fund & 0 & 0 & 0 & 0 & 168 & 445 & 863 & 300 & 300 & 331 \\
\hline Net lending & 0 & 0 & 0 & -481 & 0 & 0 & $-1,743$ & 0 & 0 & 0 \\
\hline Fiscal balance & $-1,981$ & $-4,662$ & $-12,968$ & $-24,858$ & $-24,312$ & $-40,235$ & $-36,489$ & $-41,375$ & $-31,088$ & $-24,080$ \\
\hline Primary balance & 1,437 & $-1,926$ & $-9,872$ & $-21,082$ & $-15,950$ & $-31,885$ & $-28,618$ & $-32,467$ & $-22,180$ & $-13,589$ \\
\hline Financing & 1,981 & 4,662 & 12,968 & 24,858 & 24,312 & 40,235 & 36,489 & 41,375 & 31,088 & 24,080 \\
\hline Privatization proceeds & 3,660 & 1,500 & 600 & 371 & 0 & 0 & 0 & 0 & 0 & 0 \\
\hline External & 1,492 & 732 & 324 & 2,284 & 14,715 & & 21,930 & & 10,844 & 1,103 \\
\hline Domestic & $-3,171$ & 2,430 & 12,044 & 22,203 & 9,596 & & 14,560 & & 20,044 & 22,977 \\
\hline \multicolumn{11}{|l|}{ Financial liabilities } \\
\hline Gross public debt 4/ & 59,011 & 63,341 & 82,324 & 109,752 & 134,347 & 149,987 & 147,018 & 188,393 & 177,906 & 201,986 \\
\hline Gross public debt excl. guarantees & 45,179 & 53,019 & 72,747 & 100,435 & 125,597 & 141,647 & 138,678 & 180,053 & 169,566 & 193,646 \\
\hline External & 30,686 & 27,341 & 29,672 & 35,733 & 49,954 & 60,632 & 57,663 & 78,994 & 68,507 & 69,610 \\
\hline Domestic & 14,493 & 25,678 & 43,075 & 64,702 & 75,643 & 81,015 & 81,015 & 101,059 & 101,059 & 124,036 \\
\hline Other liabilities & & & & & & & & & & \\
\hline
\end{tabular}

Sources: Ministry of Finance; Eurostat; and Fund staff projections.

1/ Increase in 2009 mostly reflects higher EU-financed capital spending and budgeted rise in pensions.

2/ Includes co-financing of EU projects.

3/ Does not include all capital spending. Total investment increased from 6.0 percent of GDP in 2008 to 7.0 percent of GDP in the authorities' 2009 budget.

4/ Total public debt, including government debt, local government debt, and guarantees. 
Table 7. Romania: Monetary Survey, 2005-11

(In millions of lei (RON), unless otherwise indicated; end of period)

\begin{tabular}{|c|c|c|c|c|c|c|c|c|}
\hline & \multirow{2}{*}{ Dec-05 } & \multirow[t]{2}{*}{ Dec-06 } & \multirow[t]{2}{*}{ Dec-07 } & \multirow[t]{2}{*}{ Dec-08 } & \multicolumn{2}{|c|}{ Dec-09 } & \multirow{2}{*}{$\begin{array}{r}\text { Dec-10 } \\
\text { Proj. } \\
\end{array}$} & \multirow{2}{*}{$\begin{array}{r}\text { Dec-11 } \\
\text { Proj. } \\
\end{array}$} \\
\hline & & & & & Prog. & Rev.prog. & & \\
\hline \multicolumn{9}{|c|}{ I. Banking System } \\
\hline Net foreign assets & 41,501 & 38,734 & 29,076 & 13,138 & $-31,151$ & $-5,962$ & $-3,734$ & 585 \\
\hline In million euros & 11,286 & 11,454 & 8,225 & 3,323 & $-6,796$ & $-1,408$ & -826 & 135 \\
\hline o/w commercial banks & $-6,511$ & $-11,094$ & $-18,666$ & $-24,388$ & $-25,693$ & $-27,007$ & $-27,007$ & $-27,007$ \\
\hline Net domestic assets & 45,025 & 72,087 & 119,039 & 160,890 & 216,750 & 187,034 & 194,925 & 203,544 \\
\hline Public sector credit, net & 3,297 & 3,546 & 9,571 & 17,268 & 26,865 & 31,765 & 51,809 & 74,786 \\
\hline Private sector credit & 59,806 & 92,379 & 148,181 & 198,086 & 230,587 & 194,640 & 205,488 & 232,616 \\
\hline Other & $-18,078$ & $-23,837$ & $-38,712$ & $-54,464$ & $-40,702$ & $-39,371$ & $-62,371$ & $-103,858$ \\
\hline Broad Money (M3) & 86,526 & 110,821 & 148,116 & 174,028 & 185,600 & 181,072 & 191,192 & 204,130 \\
\hline Intermediate money (M2) & 86,230 & 110,442 & 148,044 & 173,629 & 185,248 & 180,695 & 190,794 & 203,705 \\
\hline Money market instruments & 295 & 379 & 72 & 399 & 352 & 377 & 398 & 425 \\
\hline Narrow money (M1) & 33,760 & 48,726 & 79,914 & 92,605 & 98,741 & 89,221 & 94,208 & 106,578 \\
\hline Currency in circulation & 11,386 & 15,130 & 21,442 & 25,314 & 28,656 & 27,970 & 29,533 & 29,699 \\
\hline Overnight deposits & 22,375 & 33,596 & 58,473 & 67,291 & 70,085 & 61,251 & 64,674 & 76,879 \\
\hline \multicolumn{9}{|c|}{ II. National Bank of Romania } \\
\hline Net foreign assets & 65,443 & 76,251 & 96,466 & 110,323 & 86,619 & 108,432 & 118,284 & 117,464 \\
\hline In million euros & 17,797 & 22,548 & 27,289 & 27,901 & 18,897 & 25,599 & 26,180 & 27,142 \\
\hline Net domestic assets & $-43,231$ & $-41,671$ & $-47,593$ & $-59,855$ & $-29,488$ & $-52,669$ & $-59,404$ & $-58,254$ \\
\hline Public sector credit, net & $-3,943$ & $-9,562$ & $-8,499$ & $-1,428$ & $-5,449$ & $-1,428$ & $-1,428$ & $-1,428$ \\
\hline Credit to banks, net & $-23,224$ & $-11,098$ & $-4,034$ & 853 & 30,238 & 3,039 & $-3,697$ & $-2,546$ \\
\hline Other & $-16,064$ & $-21,011$ & $-35,060$ & $-59,280$ & $-54,277$ & $-54,280$ & $-54,280$ & $-54,280$ \\
\hline Reserve money & 22,212 & 34,580 & 48,873 & 50,468 & 57,131 & 55,763 & 58,880 & 59,210 \\
\hline \multicolumn{9}{|c|}{ (Annual percentage change) } \\
\hline Broad money (M3) & 36.5 & 28.1 & 33.7 & 17.5 & 6.6 & 4.0 & 5.6 & 6.8 \\
\hline NFA contribution & 9.7 & -3.2 & -8.7 & -10.8 & -25.4 & -11.0 & 1.2 & 2.3 \\
\hline NDA contribution & 26.8 & 31.3 & 42.4 & 28.3 & 32.0 & 15.0 & 4.4 & 4.5 \\
\hline Reserve money & 62.1 & 55.7 & 41.3 & 3.3 & 13.2 & 10.5 & 5.6 & 0.6 \\
\hline NFA contribution & 182.2 & 48.7 & 58.5 & 28.4 & -46.8 & -3.7 & 17.7 & -1.4 \\
\hline NDA contribution & -120.1 & 7.0 & -17.1 & -25.1 & 60.0 & 14.2 & -12.1 & 2.0 \\
\hline Domestic credit, real & 32.3 & 44.9 & 54.3 & 28.4 & 14.4 & 0.8 & 10.3 & 18.1 \\
\hline Private sector, at constant e/r & 52.0 & 60.1 & 58.2 & 25.6 & 7.4 & -5.6 & 1.6 & 16.7 \\
\hline Public sector, real & 5.2 & 2.6 & 153.3 & 69.1 & 48.9 & 77.0 & 58.4 & 42.7 \\
\hline Broad money (M3), at constant e/r & 25.6 & 22.1 & 25.4 & 10.5 & 2.0 & -0.2 & 2.5 & 5.6 \\
\hline Private deposits, at constant e/r & 35.0 & 32.5 & 31.7 & 13.0 & 1.6 & 1.3 & 3.6 & 7.8 \\
\hline \multicolumn{9}{|l|}{ Memorandum items: } \\
\hline CPI inflation, eop & 8.6 & 4.9 & 6.6 & 6.3 & 4.5 & 4.3 & 3.0 & 3.2 \\
\hline Inflation target & $6.5-8.5$ & $4-6$ & $3-5$ & $2.8-4.8$ & $2.5-4.5$ & $2.5-4.5$ & $2.5-4.5$ & $\ldots$ \\
\hline \multicolumn{9}{|l|}{ Interest rates (percent): } \\
\hline Policy interest rate & 7.50 & 8.75 & 7.50 & 10.25 & $\ldots$ & $\ldots$ & $\ldots$ & $\ldots$ \\
\hline Interbank offer rate, 1 week & 7.00 & 7.42 & 7.81 & 13.90 & $\ldots$ & $\ldots$ & $\ldots$ & $\ldots$ \\
\hline Corporate loans $1 /$ & 12.90 & 11.50 & 11.60 & 19.50 & $\ldots$ & $\ldots$ & $\ldots$ & $\ldots$ \\
\hline Household deposits $1 /$ & 5.20 & 6.50 & 6.92 & 15.27 & $\ldots$ & $\ldots$ & $\ldots$ & $\ldots$ \\
\hline Share of foreign currency deposits in $\mathrm{M} 3$ & 28.8 & 27.5 & 27.9 & 30.3 & $\ldots$ & $\ldots$ & $\ldots$ & $\ldots$ \\
\hline Share of foreign currency private loans & 54.7 & 47.3 & 54.3 & 57.8 & & & . & \\
\hline M2 velocity & 3.34 & 3.12 & 2.79 & 2.90 & 2.79 & 2.75 & 2.75 & 2.85 \\
\hline Money multiplier (M3/reserve money) & 3.90 & 3.20 & 3.03 & 3.45 & 3.25 & 3.25 & 3.25 & 3.45 \\
\hline
\end{tabular}

Sources: National Bank of Romania; and Fund staff estimates.

1/ Rates for new local currency denominated transactions. 
Table 8. Romania: Schedule of Reviews and Purchases

\begin{tabular}{lccl}
\hline \multicolumn{1}{c}{ Date } & \multicolumn{2}{c}{ Amount of Purchase } & \\
\cline { 2 - 3 } May 6, 2009 & Millions of SDRs & Percent of Quota & \\
September 15, 2009 & 4,370 & 424.19 & Approval of arrangement \\
December 15, 2009 & 1,718 & 166.76 & First review and end-June 2009 performance criteria \\
March 15, 2010 & 1,409 & 136.77 & Second review and end-September 2009 performance criteria \\
June 15, 2010 & 766 & 74.35 & Third review and end-December 2009 performance criteria \\
September 15, 2010 & 768 & 74.55 & Fourth review and end-March 2010 performance criteria \\
December 15, 2010 & 769 & 74.65 & Fifth review and end-June 2010 performance criteria \\
March 15, 2011 & 769 & 74.65 & Sixth review and end-September 2010 performance criteria \\
& 874 & 84.84 & Seventh and end-December 2010 performance criteria \\
Total & & & \\
\hline
\end{tabular}

Source: IMF staff estimates. 
Table 9. Romania: Indicators of Fund Credit, 2009-16 1/ (In millions of SDR)

\begin{tabular}{|c|c|c|c|c|c|c|c|c|}
\hline & 2009 & 2010 & 2011 & 2012 & 2013 & 2014 & 2015 & 2016 \\
\hline \multicolumn{9}{|l|}{ Existing Fund Credit } \\
\hline Stock 2/ & 4,370 & 4,370 & 4,370 & 3,278 & 1,093 & 0 & 0 & 0 \\
\hline Obligations 3/ & 14 & 57 & 57 & 1,148 & 2,217 & 1,098 & 0 & 0 \\
\hline Repurchase & 0 & 0 & 0 & 1,093 & 2,185 & 1,093 & 0 & 0 \\
\hline Charges & 14 & 57 & 57 & 55 & 32 & 6 & 0 & 0 \\
\hline \multicolumn{9}{|c|}{ Prospective Fund Credit under Stand-By Arrangement } \\
\hline Disbursement & 3,127 & 3,072 & 874 & 0 & 0 & 0 & 0 & 0 \\
\hline Stock 2/ & 3,127 & 6,199 & 7,073 & 6,858 & 4,719 & 1,507 & 109 & 0 \\
\hline Obligations 3/ & 19 & 65 & 91 & 307 & 2,222 & 3,263 & 1,412 & 110 \\
\hline Repurchase & 0 & 0 & 0 & 215 & 2,139 & 3,213 & 1,398 & 109 \\
\hline Charges & 19 & 65 & 91 & 92 & 83 & 50 & 14 & 1 \\
\hline \multicolumn{9}{|l|}{ Stock of existing and prospective Fund credit } \\
\hline In millions of SDR & 7,497 & 10,569 & 11,443 & 10,136 & 5,812 & 1,507 & 109 & 0 \\
\hline In percent of quota & 728 & 1,026 & 1,111 & 984 & 564 & 146 & 11 & 0 \\
\hline In percent of GDP & 7.1 & 9.8 & 9.6 & 7.3 & 3.7 & 0.8 & 0.1 & 0.0 \\
\hline In percent of exports of goods and services & 23.8 & 31.7 & 32.6 & 27.0 & 14.4 & 3.5 & 0.2 & 0.0 \\
\hline In percent of gross reserves & 24.9 & 31.1 & 32.0 & 27.4 & 16.0 & 4.4 & 0.3 & 0.0 \\
\hline \multicolumn{9}{|c|}{ Obligations to the Fund from existing and prospective Fund arrangements } \\
\hline In millions of SDR & 33 & 122 & 148 & 1,455 & 4,439 & 4,361 & 1,412 & 110 \\
\hline In percent of quota & 3.2 & 11.9 & 14.4 & 141.2 & 430.9 & 423.3 & 137.1 & 10.7 \\
\hline In percent of GDP & 0.0 & 0.1 & 0.1 & 1.1 & 2.8 & 2.4 & 0.7 & 0.0 \\
\hline In percent of exports of goods and services & 0.1 & 0.4 & 0.4 & 3.9 & 11.0 & 10.0 & 3.0 & 0.2 \\
\hline In percent of gross reserves & 0.1 & 0.4 & 0.4 & 3.9 & 12.2 & 12.6 & 4.3 & 0.4 \\
\hline
\end{tabular}

1/ Using SDR interest rate as well as exchange rate of SDR/US\$ and US\$/€ of August 20, 2009.

2/ End of period.

3/ Repayment schedule based on repurchase obligations. 
Table 10. Romania: Public Sector Debt Sustainability Framework, 2004-14 (In percent of GDP, unless otherwise indicated)

\begin{tabular}{|c|c|c|c|c|c|c|c|c|c|c|c|c|}
\hline & \multicolumn{5}{|c|}{ Actual } & \multicolumn{6}{|c|}{ Projections } & \multirow{3}{*}{$\begin{array}{c}\text { Debt-stabilizing } \\
\text { primary } \\
\text { balance } 9 /\end{array}$} \\
\hline & 2004 & 2005 & 2006 & 2007 & 2008 & 2009 & 2010 & 2011 & 2012 & 2013 & 2014 & \\
\hline \multirow{3}{*}{$\begin{array}{l}\text { Baseline: Public sector debt } 1 / \\
\text { o/w foreign-currency denominated }\end{array}$} & & & & & & & & & & & & \\
\hline & 17.4 & 15.6 & 15.4 & 17.6 & 19.9 & 27.9 & 32.3 & 33.4 & 32.3 & 30.5 & 28.9 & -1.7 \\
\hline & 10.1 & 8.8 & 7.2 & 6.5 & 6.7 & 17.0 & 22.2 & 19.9 & 16.9 & 13.1 & 9.6 & \\
\hline Change in public sector debt & -8.4 & -1.7 & -0.3 & 2.2 & 2.3 & 8.0 & 4.4 & 1.1 & -1.1 & -1.8 & -1.6 & \\
\hline Identified debt-creating flows $(4+7+12)$ & -3.8 & -2.5 & -2.9 & 0.1 & 2.8 & 7.6 & 4.4 & 1.1 & -1.1 & -1.8 & -1.6 & \\
\hline Primary deficit & 2.1 & -0.4 & 0.6 & 2.4 & 4.2 & 5.8 & 4.2 & 2.3 & 1.0 & 0.5 & 0.1 & \\
\hline Revenue and grants & 29.9 & 31.4 & 32.3 & 32.5 & 32.8 & 31.6 & 31.7 & 31.6 & 31.6 & 31.6 & 31.3 & \\
\hline Primary (noninterest) expenditure & 32.1 & 31.0 & 32.9 & 34.9 & 37.0 & 37.4 & 36.0 & 33.9 & 32.6 & 32.1 & 31.4 & \\
\hline Automatic debt dynamics $2 /$ & -5.3 & -0.9 & -3.0 & -2.2 & -1.3 & 1.8 & 0.2 & -1.2 & -2.1 & -2.2 & -1.7 & \\
\hline Contribution from interest rate/growth differential 3/ & -3.9 & -1.5 & -1.7 & -1.8 & -2.4 & 1.8 & 0.2 & -1.2 & -2.1 & -2.2 & -1.7 & \\
\hline Of which contribution from real interest rate & -2.2 & -0.8 & -0.7 & -1.0 & -1.4 & 0.1 & 0.4 & 0.1 & -0.1 & -0.3 & -0.3 & \\
\hline Of which contribution from real GDP growth & -1.7 & -0.6 & -1.0 & -0.8 & -1.0 & 1.7 & -0.1 & -1.4 & -2.0 & -1.9 & -1.4 & \\
\hline Contribution from exchange rate depreciation $4 /$ & -1.4 & 0.6 & -1.3 & -0.4 & 1.1 & $\ldots$ & $\ldots$ & & & $\ldots$ & $\ldots$ & \\
\hline Other identified debt-creating flows & -0.6 & -1.3 & -0.4 & -0.1 & -0.1 & 0.0 & 0.0 & 0.0 & 0.0 & 0.0 & 0.0 & \\
\hline Privatization receipts (negative) & -0.6 & -1.3 & -0.4 & -0.1 & -0.1 & 0.0 & 0.0 & 0.0 & 0.0 & 0.0 & 0.0 & \\
\hline Recognition of implicit or contingent liabilities & 0.0 & 0.0 & 0.0 & 0.0 & 0.0 & 0.0 & 0.0 & 0.0 & 0.0 & 0.0 & 0.0 & \\
\hline Other (specify, e.g. bank recapitalization) & 0.0 & 0.0 & 0.0 & 0.0 & 0.0 & 0.0 & 0.0 & 0.0 & 0.0 & 0.0 & 0.0 & \\
\hline Residual, including asset changes (2-3) 5/ & -4.6 & 0.7 & 2.6 & 2.2 & -0.5 & 0.4 & 0.0 & 0.0 & 0.0 & 0.0 & 0.0 & \\
\hline Public sector debt-to-revenue ratio $1 /$ & 58.0 & 49.8 & 47.6 & 54.2 & 60.7 & 88.2 & 101.7 & 105.7 & 102.1 & 96.5 & 92.3 & \\
\hline Gross financing need $6 /$ & 4.2 & 1.6 & 1.8 & 3.8 & 5.7 & 8.3 & 7.2 & 6.3 & 5.0 & 5.3 & 5.0 & \\
\hline in billions of U.S. dollars & 3.1 & 1.6 & 2.2 & 6.4 & 11.4 & 13.3 & 12.0 & 11.6 & 10.5 & 12.8 & 13.8 & \\
\hline Scenario with key variables at their historical averages $7 /$ & & & & & & 27.9 & 25.3 & 23.5 & 21.7 & 20.2 & 18.8 & -2.5 \\
\hline Scenario with no policy change (constant primary balance) in 2009-2014 & & & & & & 27.9 & 34.5 & 40.0 & 42.9 & 45.6 & 48.7 & -2.9 \\
\hline \multicolumn{13}{|l|}{ Key Macroeconomic and Fiscal Assumptions Underlying Baseline } \\
\hline Real GDP growth (in percent) & 8.5 & 4.1 & 7.9 & 6.2 & 7.1 & -8.5 & 0.5 & 4.6 & 6.6 & 6.8 & 5.0 & \\
\hline Average nominal interest rate on public debt (in percent) $8 /$ & 6.2 & 7.0 & 6.0 & 5.8 & 5.2 & 7.8 & 6.4 & 6.2 & 6.0 & 5.6 & 5.2 & \\
\hline Average real interest rate (nominal rate minus change in GDP deflator, in percent) & -9.3 & -5.2 & -4.5 & -6.9 & -8.8 & 0.0 & 1.4 & 0.7 & 0.0 & -0.6 & -1.0 & \\
\hline Nominal appreciation (increase in US dollar value of local currency, in percent) & 14.2 & -6.2 & 19.4 & 6.5 & -16.5 & $\ldots$ & $\ldots$ & $\ldots$ & $\ldots$ & $\ldots$ & $\ldots$ & \\
\hline Inflation rate (GDP deflator, in percent) & 15.5 & 12.2 & 10.5 & 12.8 & 14.0 & 7.8 & 5.1 & 5.5 & 6.0 & 6.2 & 6.2 & \\
\hline Growth of real primary spending (deflated by GDP deflator, in percent) & 20.4 & 0.8 & 14.4 & 12.7 & 13.7 & -7.6 & -3.3 & -1.3 & 2.5 & 5.1 & 2.7 & \\
\hline Primary deficit & 2.1 & -0.4 & 0.6 & 2.4 & 4.2 & 5.8 & 4.2 & 2.3 & 1.0 & 0.5 & 0.1 & \\
\hline
\end{tabular}

1/ Coverage: general government. Gross public debt excluding guarantees is used.

2/ Derived as $[(r-\pi(1+g)-g+\alpha \varepsilon(1+r)] /(1+g+\pi+g \pi))$ times previous period debt ratio, with $r=$ interest rate; $\pi=$ growth rate of GDP deflator; $g=$ real GDP growth rate; $\alpha=$ share of foreign-currency denominated debt; and $\varepsilon=$ nominal exchange rate depreciation (measured by increase in local currency value of U.S. dollar).

$3 /$ The real interest rate contribution is derived from the denominator in footnote $2 /$ as $r-\pi(1+g)$ and the real growth contribution as $-g$

4/ The exchange rate contribution is derived from the numerator in footnote $2 /$ as $\alpha \varepsilon(1+r)$.

$6 /$ / Defined as ans, this line includes exchange rate changes.

$7 /$ The key variables include real GDP growth; real interest rate; and primary balance in percent of GDP.

8/ Derived as nominal interest expenditure divided by previous period debt stock.

9/ Assumes that key variables (real GDP growth, real interest rate, and other identified debt-creating flows) remain at the level of the last projection year. 
Table 11. Romania: External Debt Sustainability Framework, 2004-14

(In percent of GDP, unless otherwise indicated)

\begin{tabular}{|c|c|c|c|c|c|c|c|c|c|c|c|c|}
\hline & \multicolumn{5}{|c|}{ Actual } & \multicolumn{7}{|c|}{ Projections } \\
\hline & 2004 & 2005 & 2006 & 2007 & 2008 & 2009 & 2010 & 2011 & 2012 & 2013 & 2014 & \multirow{17}{*}{$\begin{array}{c}\text { Debt-stabilizing } \\
\text { non-interest } \\
\text { current account 6/ } \\
-8.2\end{array}$} \\
\hline Baseline: External debt & 35.2 & 38.8 & 42.1 & 47.3 & 53.7 & 67.7 & 70.8 & 66.7 & 59.1 & 51.7 & 45.8 & \\
\hline Change in external debt & 1.4 & 3.6 & 3.3 & 5.2 & 6.3 & 14.0 & 3.1 & -4.1 & -7.6 & -7.4 & -5.9 & \\
\hline Identified external debt-creating flows $(4+8+9)$ & -4.7 & -6.6 & -5.3 & -1.3 & 1.9 & 6.9 & 1.1 & -1.8 & -2.6 & -2.3 & -1.1 & \\
\hline Current account deficit, excluding interest payments & 7.1 & 7.5 & 9.3 & 12.3 & 10.0 & 2.3 & 2.3 & 2.8 & 3.1 & 3.5 & 3.7 & \\
\hline Deficit in balance of goods and services & 9.1 & 10.2 & 12.0 & 14.0 & 12.8 & 6.6 & 7.1 & 6.8 & 7.2 & 7.5 & 7.6 & \\
\hline Exports & 35.8 & 33.0 & 32.2 & 29.5 & 31.0 & 30.0 & 30.8 & 29.4 & 27.2 & 25.4 & 24.3 & \\
\hline Imports & 44.8 & 43.2 & 44.2 & 43.5 & 43.8 & 36.5 & 37.9 & 36.3 & 34.4 & 32.9 & 31.9 & \\
\hline Net non-debt creating capital inflows (negative) & -8.4 & -6.9 & -8.5 & -6.0 & -5.9 & -3.9 & -4.3 & -4.9 & -4.9 & -4.9 & -4.9 & \\
\hline Automatic debt dynamics $1 /$ & -3.4 & -7.1 & -6.1 & -7.6 & -2.2 & 8.4 & 3.1 & 0.3 & -0.9 & -0.9 & 0.0 & \\
\hline Contribution from nominal interest rate & 1.3 & 1.2 & 1.1 & 1.2 & 2.4 & 3.2 & 3.4 & 3.3 & 2.9 & 2.6 & 2.3 & \\
\hline Contribution from real GDP growth & -2.5 & -1.1 & -2.5 & -2.1 & -3.0 & 5.3 & -0.3 & -3.0 & -3.8 & -3.5 & -2.3 & \\
\hline Contribution from price and exchange rate changes $2 /$ & -2.2 & -7.1 & -4.7 & -6.7 & -1.5 & $\ldots$ & $\ldots$ & $\ldots$ & $\ldots$ & $\ldots$ & $\ldots$ & \\
\hline Residual, incl. change in gross foreign assets (2-3) $3 /$ & 6.1 & 10.1 & 8.6 & 6.5 & 4.4 & 7.1 & 2.0 & -2.3 & -5.0 & -5.1 & -4.8 & \\
\hline External debt-to-exports ratio (in percent) & 98.5 & 117.4 & 130.9 & 160.5 & 173.1 & 225.7 & 229.8 & 226.6 & 217.4 & 203.5 & 188.4 & \\
\hline Gross external financing need (in billions of US dollars) $4 /$ & 9.8 & 13.7 & 21.4 & 34.5 & 45.6 & 37.7 & 36.3 & 38.0 & 41.3 & 46.4 & 50.8 & \\
\hline in percent of GDP & 16.1 & 17.2 & 21.9 & 27.9 & 33.3 & 32.0 & 30.3 & 29.0 & 27.0 & 26.3 & 25.4 & \\
\hline Scenario with key variables at their historical averages 5 / & & & & & & 67.7 & 64.0 & 59.0 & 54.3 & 49.1 & 44.2 & -10.7 \\
\hline \multicolumn{13}{|l|}{ Key Macroeconomic Assumptions Underlying Baseline } \\
\hline Real GDP growth (in percent) & 8.5 & 4.1 & 7.9 & 6.2 & 7.1 & -8.5 & 0.5 & 4.6 & 6.6 & 6.8 & 5.0 & \\
\hline GDP deflator in US dollars (change in percent) & 7.0 & 25.4 & 13.7 & 19.0 & 3.3 & -6.0 & 1.2 & 4.9 & 9.1 & 8.2 & 8.0 & \\
\hline Nominal external interest rate (in percent) & 4.4 & 4.3 & 3.5 & 3.6 & 5.5 & 5.1 & 5.2 & 5.1 & 5.1 & 5.0 & 5.0 & \\
\hline Growth of exports (US dollar terms, in percent) & 19.4 & 20.6 & 19.5 & 15.9 & 16.2 & -16.8 & 4.5 & 4.8 & 7.5 & 8.1 & 8.4 & \\
\hline Growth of imports (US dollar terms, in percent) & 23.4 & 25.9 & 25.4 & 24.5 & 11.3 & -28.3 & 5.4 & 5.1 & 10.4 & 10.6 & 9.8 & \\
\hline Current account balance, excluding interest payments & -7.1 & -7.5 & -9.3 & -12.3 & -10.0 & -2.3 & -2.3 & -2.8 & -3.1 & -3.5 & -3.7 & \\
\hline Net non-debt creating capital inflows & 8.4 & 6.9 & 8.5 & 6.0 & 5.9 & 3.9 & 4.3 & 4.9 & 4.9 & 4.9 & 4.9 & \\
\hline
\end{tabular}

$1 /$ Derived as $[r-g-\rho(1+g)+\varepsilon \alpha(1+r)] /(1+g+\rho+g \rho)$ times previous period debt stock, with $r=$ nominal effective interest rate on external debt; $\rho=$ change in domestic GDP deflator in US dollar terms, $\mathrm{g}=$ real GDP growth rate, $\varepsilon=$ nominal appreciation (increase in dollar value of domestic currency), and $\alpha=$ share of domestic-currency denominated debt in total external debt.

$2 /$ The contribution from price and exchange rate changes is defined as $[-\rho(1+g)+\varepsilon \alpha(1+r)] /(1+g+\rho+g \rho)$ times previous period debt stock. $\rho$ increases with an appreciating domestic currency

2/ The contribution from price and exchange rate chan

$3 /$ For projection, line includes the impact of price and exchange rate changes.

4/ Defined as current account deficit, plus amortization on medium- and long-term debt, plus short-term debt at end of previous period.

5/ The key variables include real GDP growth; nominal interest rate; dollar deflator growth; and both non-interest current account and non-debt inflows in percent of GDP.

6/ Long-run, constant balance that stabilizes the debt ratio assuming that key variables (real GDP growth, nominal interest rate, dollar deflator growth, and non-debt inflows in percent of GDP) remain

at their levels of the last projection year. 


\section{ATTACHMENT I. ROMANIA: LETTER OF INTENT (LOI)}

Mr. Dominique Strauss-Kahn

Bucharest, September 8, 2009

Managing Director

International Monetary Fund

Washington, DC, 20431

U.S.A.

Dear Mr. Strauss-Kahn:

1. Romania is facing a severe economic downturn. While implementation of our comprehensive anti-crisis program supported by the Fund, the EU, and the World Bank has succeeded in normalizing financial conditions, the contraction in economic activity has been much sharper than projected due to a combination of an unfavorable external environment and faster retrenchment of domestic demand. We anticipate that the economic environment will remain difficult for the remainder of 2009 , with only a gradual improvement during 2010.

2. Notwithstanding the challenging environment, implementation by the authorities of the IMF-supported program has been strong (Tables 1 and 2):

- $\quad$ Quantitative performance criteria and inflation consultation mechanism. All quantitative performance criteria for end-June 2009 and the continuous performance criterion on non-accumulation of external arrears have been met, with the exception of the ceiling on general government domestic arrears, which was exceeded (by 0.1 percent of GDP) due to increased arrears at the central and local government levels. The indicative target on general government primary spending was also met. Inflation was within the inner band of the inflation consultation mechanism.

- $\quad$ Structural benchmarks. The end-August 2009 structural performance criterion on ratification by parliament of fiscal adjustment measures was met in April. The structural benchmark for end-June for amending deposit insurance legislation was also met, and we will consider taking further measures in order to speed up implementation and improve the financing mechanisms for the deposit guarantee.

3. In view of this performance, we request completion of the first review under the Stand-By Arrangement. On the basis of the corrective measures being taken and the 
additional explanations given in this Letter, we request a waiver for the end-June 2009 performance criterion on general government arrears.

4. We believe that the policies set forth in the letter of April 24, 2009 and in this letter are adequate to achieve the objectives of our economic program, and the Government stands ready to take additional measures as appropriate to ensure achievement of its objectives. As is standard under all IMF arrangements, we will consult with the IMF before modifying measures contained in this letter or adopting new measures that would deviate from the goals of the program, and provide the IMF and the European Commission with the necessary information for program monitoring.

\section{Macroeconomic Framework for 2009 and 2010}

5. Domestic demand had declined more than anticipated at the time the program was agreed. Real GDP contracted by 6.2 percent (yoy) in the first quarter and we expect a further drop in the second quarter. For the year, we now expect a severe contraction of -8 to $-8 \frac{1}{2}$ percent, with only a modest recovery in 2010 , as weak financial conditions in households and rising unemployment will keep domestic demand low. External demand will improve only in line with the recovery elsewhere in Europe. The sizable output gap has helped contain price increases, and inflation has been easing; we now expect 4.3 percent growth in the CPI in 2009, followed by an easing to below 3 percent in 2010.

6. The contraction in domestic demand has set off a faster correction in external imbalances. The current account deficit fell by about $3 / 4$ in the first five months of 2009 compared to the same period of 2008, with both exports and imports falling at a sharper pace than projected under the program (around 20 and 35 percent yoy, respectively). In addition, developments in the external capital and financial account have been somewhat better than projected under the program, as a slightly lower rollover of exposures by foreign banks has been more than offset by higher rollover by corporates and stronger FDI inflows. We now project that external imbalances will adjust faster than anticipated in the original program for the year as whole. The current account deficit is expected to decline to $5 \frac{1}{2}$ percent in 2009 (compared to $7 \frac{1}{2}$ in the original program) from 12.4 percent of GDP in 2008. External financing is also projected to hold up better than expected in the original program. As a result, the NFA are projected to be about $€ 4$ billion above end-2009 program targets.

\section{Fiscal Sector}

7. Despite worsening economic conditions, efforts to control expenditure in the central government allowed us to meet the general government deficit target for end-June 2009 notwithstanding overruns in some decentralized government entities. As economic conditions remain weak, however, the deficit will rise sharply in the second half of the year. Absent further measures, deteriorating growth, lower revenue yields, and overruns in current spending, notably wages, would push the deficit to a projected 8.1 percent of GDP from the 
4.6 percent agreed. Revenues are expected to fall by some RON $17 \frac{1}{2}$ billion ( $3 \frac{1}{2}$ percent of GDP) compared to the original program, as VAT tax revenues, social contributions, and nontax revenues fall well short. On the expenditure side, bonus reductions and reduced staffing are producing some impact on the wage bill, but carry-over from large increases last year, especially outside the central government, have led to much higher-than-programmed increases in wages and salaries. Goods and services spending, while declining relative to last year, is also well above our desired level, while other spending has fallen short of our objectives. Together, these trends would produce excess outlays of around RON 3.3 billion (0.7 percent of GDP).

8. To strike an appropriate balance between the short-term need to allow automatic stabilizers to work and the medium-term adjustment objectives, we are committed to taking additional policy actions to limit the fiscal deficit in 2009 and to reducing it in 2010. For 2009, this will imply an additional adjustment of 0.8 percent of GDP - not only by reversing the spending overruns, but bringing total expenditures to some RON 5.7 billion below the original program level-producing a deficit of 7.3 percent of GDP while improving the composition of expenditures. This implies an adjustment of 2.2 percent of GDP in structural terms. To help eliminate overruns in current expenditure, we will establish a quarterly ceiling on current spending minus certain transfers and social payments as an indicative target under the program beginning with end-September. ${ }^{1}$ We will undertake several emergency measures to reduce the wage bill: (i) between October and the end of December 2009, all personnel spending (including in the local governments and self-financed entities) will be subject to a reduction of $15 \frac{1}{2}$ percent, corresponding to a reduction in working hours equivalent to 10 working days ( 0.3 percent of GDP); (ii) overtime hours and premia will be cut as well, yielding an additional 0.1 percent of GDP; and (iii) we will launch the restructuring of state agencies, as described in paragraph 12 below. Other current spending will be curtailed compared to the trend in the first half of the year $(0.2$ percent of GDP), comprising both discretionary cuts and automatic reductions in local government and decentralized entities' spending due to lack of own resources. The capital budget will be trimmed by 0.2 percent of GDP, while preserving room for a realistic investment budget in the coming months. Government approval of legislation, including a revised 2009 budget, to apply these commitments at all levels of government will be a prior action for the completion of this review. To finance the higher fiscal deficit in 2009 relative to our original program target, we intend to have half of the remaining IMF disbursements for 2009 of SDR 3.1 billion be channeled directly to the government.

9. To reduce the risk of further payments arrears, we will take a number of corrective measures at the local and central government levels. In particular, we will: (i) clear all arrears accumulated so far this year by end-September 2009 and the entire stock of remaining arrears

${ }^{1}$ This target will replace the primary spending ceiling indicative target established previously. 
(which turned out higher than estimated earlier) by end-2010; (ii) we will condition access of local and self-financed government entities to central government guarantees and additional transfer payments on satisfactory performance in reducing or eliminating such arrears; and (iii) we will initiate a review of the commitment control systems with a view to strengthening it during 2010 (see $\$ 14$ below). We will increase the ceiling on public guarantees to RON7.7 billion in 2009 and RON 8.6 billion in 2010, but will insist that the increase in guarantees relative to the original ceiling of RON 6 billion be devoted exclusively to financing the counterpart payments of investment projects financed by the EU or other multilateral institutions. We are aware of an increase in delays in payments for VAT refunds to exporters, and are undertaking steps to sharply reduce these delays, and clear the stock of existing arrears by end-September 2009. We have set-up national guidelines for VAT refund applicable to all local tax administrations, ensuring that claims are processed in the order they are received and within 45 days. We are implementing an online follow-up system that will allow exporters to verify the status of their claims. We will also implement recommendations of the recent IMF technical assistance mission on improving the VAT refund processes (see $\mathbb{q 1 6}$ ).

10. For 2010, we remain fully committed to taking further measures to bring the deficit to a more sustainable level in line with the July 104.7 Council recommendations. For that year, we plan to reduce the deficit to below 6 percent of GDP, an adjustment of about $2 \frac{1}{2}$ percentage points of GDP in structural terms compared to 2009. On the expenditure side, we will implement measures to reduce the wage bill further, including a freeze on wages as described in $\$ 12$ ( 0.3 percent of GDP), a continuation of the replacement of only 1 of 7 departing workers and cuts in overtime and premia ( 0.25 percent of GDP), and structural changes to reduce employment and restructure the wage system ( $\$ 12)$. Savings from implementation of the pension reform law ( $(13)$ due to a higher contribution base, better control on fraudulent disability pension claims, and fewer earlier retirements should yield another 0.1 percent of GDP. A freeze on goods and services, pensions (excluding social pensions) and certain transfers, together with increased application of electronic procurement systems and some cuts in goods and services and other expenditures, are expected to yield another 0.9 percent of GDP. On the revenue side, revaluation of the tax base on property taxes and increased excises on tobacco and fuel (already legislated) will contribute 0.3 percent of GDP. We will also continue our efforts to improve the absorption of EU funds, while ensuring they target the right growth priorities. Approval of the 2010 budget in line with these commitments will be a structural benchmark for end-2009.

11. Crucial to our fiscal strategy will be a series of measures to produce longer-term savings and improve the quality of public finances via public sector reforms. We contemplate actions in six areas: (i) restructuring the public sector to reduce government employment, together with a reform of the wage system; (ii) pension reform; (iii) implementation of a Fiscal Responsibility Law and the medium-term budgetary framework; (iv) public enterprise reform; (v) restructuring the financial relations with the local governments and self-financed 
entities to assure greater financial accountability; (vi) improvements in tax administration; and (vii) streamlined social assistance programs.

12. Public employment and the compensation system. We are firmly committed to rationalizing the structure of the civil service at all levels of government. By end-2009, we will approve legislation that will produce significant reductions of public sector wage bill to secure additional gross savings of 0.68 percent of GDP (at least 0.49 percent of GDP net) in $2010 .^{2}$ This will be achieved by: (i) applying standardized norms for personnel costs and for goods and services spending, which will be developed and applied in the coming months at all levels of government to provide for a leaner public sector; and (ii) restructuring numerous state agencies in the government sector by either abolishing or incorporating them into relevant ministries. We reaffirm our commitment to a unified wage law to produce a simpler, fairer, more transparent, and less costly pay scale for public sector employees and to reform the bonus system. This will be achieved in two stages. In the first stage, an organic public wage law will be approved by end-October laying out the guiding principles and framework for the new unified public compensation system, containing specific annual limits for the wage bill to progressively reduce it to about 7 percent of GDP by 2015 (the levels prevailing before the last few years' excesses), freezing general government wages in 2010 (except for those earning less then RON705 per month), conditioning increases in the reference value (to which the public pay scale is indexed) after 2010 on personnel cuts needed to reach the wage bill targets as a share of GDP, as well as reforming the current system of bonuses (structural benchmark for end-October 2009). In the second stage, implementing legislation will be approved by end-September 2010 detailing the elements of the unified public compensation system, including the pay scale, in a manner consistent with the organic public wage law and fully costed by independent experts to assure savings before being submitted to parliament.

13. Pension reform. We remain committed to approving pension reforms by law by endDecember 2009. The reform will be properly costed before approval to assure adequate longterm savings. In addition to ensuring a gradual move to indexation by inflation rather than by wages, and further adjustments in the retirement age, the reform will also eliminate the costly and inequitable special regimes established for certain workers as well as revisit the conditions for early retirement to ensure that incentives provide an actuarially fair system. The reform will also include changes in the allocation of disability-related pension rights to ensure that possibilities for fraud are adequately curtailed.

14. Fiscal responsibility law. A draft FRL has been extensively discussed within the framework of the technical assistance from the Fund and benefited from further advice from

\footnotetext{
${ }^{2}$ This corresponds to RON 3,585 million in gross savings, and RON 2,571 million in net savings, for the wage bill.
} 
the EC, and we reaffirm our commitment to its submission to parliament (along with an implementation plan) by end-November. We will also request further technical assistance from the Fund on the implementation of the FRL, with a particular focus on tightening budget execution procedures and instituting commitment control systems, with a view to addressing weaknesses that led to the recent accumulation of arrears. The findings of this mission will guide our reform actions in this area during 2010.

15. Local governments. Persistent overestimation of revenues and excessive current spending in local governments present a risk to macro-fiscal stability. After consultations with the local authorities, we will change the appropriate legislation to introduce several institutional reforms to mitigate this risk: (i) all local governments requesting extra resources or breaching fiscal rules will be required to sign an adjustment program with the central government stipulating the measures they plan to take to tackle overruns and fiscal imbalances and achieve the consolidation within a reasonable amount of time, with sanctions and restructuring if the agreed conditions are not met; (ii) standard costing norms will be applied across local governments to insure fairness and improve efficiency (to be legislated by end-2009, $\$ 12$ ); (iii) movement of resources allocated for capital spending into current expenditure will be prohibited; (iv) a legal framework for local government insolvency will be established; and (v) the local government oversight unit at the Ministry of Public Finance, in collaboration with the Ministry of Administration and Interior, will be strengthened to monitor and analyze activities of local governments (structural benchmark for end-June 2010).

16. Public enterprises. To minimize the burden on public finances from state-owned enterprises (SOEs) as a result of higher subsidy requirements and lower dividend transfers, we will undertake the following legislative changes: (i) SOEs will be required to submit draft budgets to the government within 15 working days of the publication of the central government budget and collective bargaining negotiations will not be permitted until the SOE's annual budget (including its respective wage bill limits) has been approved; (ii) the total wage bill in each SOE receiving subsidies or other transfers from the budget will be established by the central government; (iii) movement of resources allocated for capital spending into current expenditure will be prohibited; (iv) automatic sanctions (personal and institutional) will be introduced for the nonobservance of the budget or of the management performance contracts; and (v) all SOEs requesting extra resources from the budget or breaching fiscal rules will be required to sign an adjustment program with the central government stipulating the measures they plan to take to improve their financial performance, with sanctions and restructuring if the agreed conditions are not met (structural benchmark for end-June 2010). We will continue to refine the monitoring system of the most problematic SOEs, with a view to setting semiannual targets on their performance at the next review. 
17. Tax administration. Progress in revenue administration is essential to recouping the loss in revenue yield related to the economic cycle and meeting our fiscal objectives. Following recommendations from a recent IMF technical assistance team, our efforts will focus on addressing VAT non-compliance and fraud, improving management of growing tax arrears, and increasing control of the largest taxpayers. First, on VAT we will refocus our audit program on higher-risk refund claims (including by scaling down the universal ex-ante and ex-post audit of cash refund claims and implementing a fast-track process for low-risk exporters) and will redirect staff to high-risk VAT refund offset claims, underreporting of sales and input credit over claims by taxpayers in a debit situation. Second, the growth in tax arrears will be addressed by improved debt management practices, including (i) the reintroduction of the authority to enter into installment agreements with taxpayers, under appropriate safeguards and in line with EU practice and (ii) amending the penalty system for noncompliance to establish separate interest and late payment charges designed to protect the real value of tax payments and to discourage nonpayment early on. Third, control of the largest taxpayers will be strengthened by: (i) ensuring that increases in taxpayers assigned to the large- and medium-size taxpayer offices are accompanied by increases in assigned audit staff; (ii) introduction of the authority to use indirect audit methods to determine taxpayers' correct tax liabilities when the records are inadequate; and (iii) directing attention toward individuals and firms where tax collection potential is highest. To improve administrative efficiency, electronic filing will be encouraged by reducing the security costs imposed on taxpayers and introducing a lower cost alternative. We will conduct further discussions with Fund staff on a timetable to direct efforts towards those taxpayers with highest tax collection potential, and approval of the necessary internal regulations and legislation to implement the remaining reforms discussed above will be a structural benchmark for end-March 2010 .

18. Social Assistance. Legislation will be approved by end-October 2009 to streamline the social benefit system by consolidating some of the more than 200 benefits currently existing and by improving targeting of the remaining programs. At the same time, allocations for unemployment and social safety net programs will be increased to help cushion the effects of the economic downturn. We will consult with the World Bank, EU and IMF in the design of this legislation. At the time of the second program review we will discuss progress on these measures with the Fund and the EU and will take additional steps, if needed, to achieve these savings.

\section{Financial Sector}

19. The Romanian banking system has so far weathered relatively well the shock generated by the deeper than anticipated contraction in economic activity. Although nonperforming loans (doubtful and loss) increased from 4.7 percent to 11.8 percent between June 2008 and June 2009, their current level is still manageable, and the system remains slightly profitable. As of end-June 2009 , the average capital adequacy ratio remained broadly stable at 13.5 percent, and all banks had a ratio above 10 percent. Following the April 2009 
stress-tests, banks with expected future capital needs in 2009 and 2010 are making good progress toward increases in own funds that will enable them to maintain their capital adequacy ratio above 10 percent over the entire program period. The NBR has received all 9 bilateral commitments letters from the parents of the largest foreign owned banks, confirming their commitments made in Vienna and Brussels, including maintaining their overall exposure to Romania. Actual exposures have fluctuated however, and we are in the process of defining with the banks and implementing a comprehensive reporting format that will allow the NBR to better monitor the evolution of such exposures.

20. We continue to improve the safety net available to deal with financial distress. We have enhanced the NBR's powers to request capital increases and restrict dividend distribution for weak credit institutions, in line with the structural benchmark for June 2009 . However, for the resolution of problem banks, upgrading our domestic legal norms while keeping in line with EU requirements has proved more complex than anticipated, and we now expect to complete this process in early 2010 (end-March 2010 structural benchmark). For deposit insurance, the government issued in June 2009 an ordinance to comply with the deadlines set in the EU directive to reduce the maximum payout period to 20 business days, and we are considering further improvements the financing regime, with a view to enhancing government support for deposit insurance. For overly indebted households, banks have implemented a decentralized approach to rescheduling and restructuring, with a view to preserving credit discipline. We do not consider that public action is needed at this time, but we will encourage banks to continue their restructuring efforts and will monitor the results closely.

21. The NBR is continuing to improve the banking supervisory and regulatory framework, consulting Fund staff prior to the introduction of key new or revised prudential regulations. Liquidity requirements and governance rules applicable to banks have been enhanced. Before further amending liquidity regulations we will conduct a more comprehensive impact study and consult the banking association about the results. Formally and permanently raising the minimum level of the capital adequacy ratio from 8 percent to 10 percent remains a medium-term objective. We remain committed to adopting the International Financial Reporting Standards (IFRS), and are consulting the Romanian Banking Association on the timetable.

\section{Monetary and Exchange Rate Policy}

22. Negotiation of the international support package has contributed to a reduction in pressure on the exchange rate. The leu has remained roughly stable against the euro since late March with no central bank intervention. The faster-than-projected improvement in the current account and the broadly unchanged outlook for the capital account have allowed for an overperformance on the performance criterion on net foreign assets at end-June. This overperformance will likely continue until the second review as well. Romania has received a 
significant SDR allocation in 2009. Given the adequate external financing provided by the multilateral support package we do not plan to use this allocation during the program period, and thus do not propose to change the NFA targets under the program.

23. With economic activity falling sharply and the exchange rate stabilizing, inflationary pressures are easing. Headline inflation fell from 6.7 percent in January to 5.1 percent by July. We expect inflation to fall further to 4.3 percent at end-2009, within the NBR's inflation targeting band. This situation has permitted the NBR to prudently relax its monetary policy stance. Since January, the central bank has reduced interest rates cumulatively by 175 b.p. in four steps, and has reduced reserve requirements on domestic and foreign currency liabilities. Looking forward, the NBR will continue to adapt its monetary policy stance as inflation and conditions in the foreign exchange market permit. However a cautious approach is warranted, as inflation in Romania remains well above the EU average and further price pressures may emerge. The NBR will continue to adequately manage liquidity with regard to evolving market conditions, in order to ensure that interest rates are appropriate for lowering inflation without jeopardizing external stability.

\section{Program monitoring}

24. The program will continue to be monitored through regular reviews, prior actions, quantitative performance criteria and indicative targets, and structural benchmarks. The quantitative targets for end-September 2009 and end-December 2009, and continuous performance criteria, are set out in Table 1; and the structural benchmarks are set out in Table 2. The understandings between the Romanian authorities and IMF staff regarding the quantitative performance criteria and the structural measures described in this memorandum are further specified in the TMU attached to this memorandum.

Gheorghe Pogea/s/

Minister of Finance
Mugur Isarescu /s/

Governor of the BNR

Attachment 
Table 1. Romania: Quantitative Program Targets

\begin{tabular}{|c|c|c|c|c|c|c|c|c|}
\hline & \multirow{3}{*}{$\begin{array}{c}2008 \\
\text { Dec } \\
\text { Actual } \\
\end{array}$} & \multicolumn{6}{|c|}{2009} & \multirow{3}{*}{$\begin{array}{c}2010 \\
\text { Dec } \\
\text { Proj } \\
\end{array}$} \\
\hline & & \multirow{2}{*}{$\begin{array}{l}\text { March } \\
\text { Actual }\end{array}$} & \multicolumn{2}{|c|}{ June } & \multicolumn{2}{|c|}{ Sept } & \multirow{2}{*}{$\begin{array}{c}\text { Dec } \\
\text { Prog } \\
\end{array}$} & \\
\hline & & & Prog & Actual & Prog & Revised & & \\
\hline \multicolumn{9}{|l|}{ I. Quantitative Performance Criteria } \\
\hline 1. Cumulative change in net foreign assets ( $\mathrm{mln}$ euros) $1 /$ & 25,532 & $-3,500$ & $-7,600$ & $-5,119$ & $-8,720$ & $-8,720$ & $-9,000$ & -500 \\
\hline 2. Cumulative floor on general government overall balance ( $\mathrm{mln}$ lei) $2 /$ & $-24,655$ & $-8,300$ & $-14,508$ & $-14,456$ & $-18,612$ & $-26,900$ & $-36,500$ & $-31,200$ \\
\hline 3. Cumulative change in general government arrears (bn lei) $1 /$ & 1.06 & 0.35 & 0.0 & 0.49 & 0.0 & 0.0 & -0.15 & -0.91 \\
\hline 4. Ceiling on general government guarantees issued during the year (face value, bn lei) & 0.0 & $\ldots$ & 6.0 & 0.02 & 6.0 & 7.7 & 7.7 & 8.6 \\
\hline \multicolumn{9}{|l|}{ II. Continuous Performance Criterion } \\
\hline 5. Nonaccumulation of external debt arrears & 0 & 0 & 0 & $\ldots$ & 0 & 0 & 0 & 0 \\
\hline \multicolumn{9}{|l|}{ III. Inflation Consultation } \\
\hline \multicolumn{9}{|l|}{ 6. 12-month rate of inflation in consumer prices } \\
\hline Outer band (upper limit) & 8.3 & 8.7 & 8.4 & $\ldots$ & 7.7 & 7.7 & 6.5 & 4.5 \\
\hline Inner band (upper limit) & 7.3 & 7.7 & 7.4 & $\ldots$ & 6.7 & 6.7 & 5.5 & 3.5 \\
\hline Center point & 6.3 & 6.7 & 6.4 & 5.9 & 5.7 & 5.7 & 4.5 & 2.5 \\
\hline Inner band (lower limit) & 5.3 & 5.7 & 5.4 & $\ldots$ & 4.7 & 4.7 & 3.5 & 1.5 \\
\hline Outer band (lower limit) & 4.3 & 4.7 & 4.4 & $\cdots$ & 3.7 & 3.7 & 2.5 & 0.5 \\
\hline \multicolumn{9}{|l|}{ IV. Indicative Target } \\
\hline 7. General government primary spending (excl. EU funds; mln lei) 2/ & 182,411 & 43,900 & 87,505 & 87,271 & 132,356 & & & \\
\hline 8. General government current primary spending (excl. EU funds and social assistance, mln lei) 2/ & 92,327 & 22,149 & & 43,238 & & 63,725 & 81,015 & 79,604 \\
\hline
\end{tabular}

1/ The December 2008 figure is a stock.

2/ The December 2008 figure is for the whole year. 
Table 2. Romania: Structural Conditionality for the Program

\begin{tabular}{|c|c|c|c|}
\hline Measure & Conditionality $1 /$ & Timing & Comments \\
\hline \multicolumn{4}{|l|}{ Fiscal policy } \\
\hline Approval of agreed measures for 2009, including revised 2009 budget (as described in LOII8) & Prior action & & \\
\hline Ratification by parliament of fiscal measures equivalent to 1.1 percent of GDP & SB & August 31, 2009 & Met in April 2009 \\
\hline 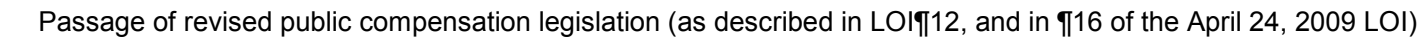 & SB & October 30, 2009 & \\
\hline $\begin{array}{l}\text { Presentation of fiscal responsibility legislation and implementation plan to parliament ( } \mathbb{1} 14 \text { of the April 24, } 2009 \\
\text { LOI) }\end{array}$ & SB & November 30, 2009 & \\
\hline Passage of revised pension legislation (as described in LOI 113 , and in $₫ 17$ of the April 24, 2009 LOI) & SB & December 31, 2009 & \\
\hline Approval of agreed 2010 budget (as described in LOI 10 ) & SB & December 31, 2009 & New conditionality \\
\hline $\begin{array}{l}\text { Approval of legislation and internal regulations necessary to implement tax administration reforms (as discussed } \\
\text { in LOIđ17) }\end{array}$ & SB & March 31, 2010 & New conditionality \\
\hline Approval of institutional reforms measures to mitigate fiscal risks from local governments and SOEs (LOIT15-16) & SB & June 30, 2010 & New conditionality \\
\hline \multicolumn{4}{|l|}{ Financial Sector } \\
\hline 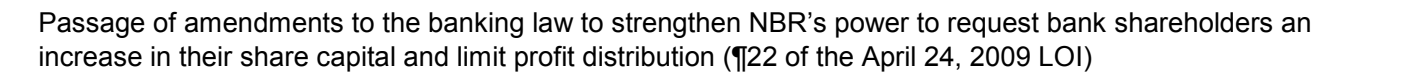 & SB & June 30, 2009 & Met \\
\hline $\begin{array}{l}\text { Passage of amendments to deposit insurance legislation to broaden grounds for activation of deposit insurance, } \\
\text { expedite payouts and provide a line of credit from the government ( }(23 \text { of the April } 24,2009 \text { LOI) }\end{array}$ & SB & August 30, 2009 & Met \\
\hline $\begin{array}{l}\text { Passage of amendments to the banking and winding-up laws to enhance the bank resolution framework, in } \\
\text { consultation with the IMF ( }(22 \text { of the April 24, } 2009 \text { LOI) }\end{array}$ & SB & November 30, 2009 & $\begin{array}{l}\text { Moved to March 31, } \\
2010\end{array}$ \\
\hline $\begin{array}{l}\text { Passage of amendments to the banking and winding-up laws to enhance the bank resolution framework, in } \\
\text { consultation with the IMF }\end{array}$ & SB & March 31, 2010 & \\
\hline
\end{tabular}




\section{AtTachment II. Romania: Technical Memorandum of Understanding (TMU)}

September 8, 2009

1. This Technical Memorandum of Understanding (TMU) updates and replaces the TMU dated April 1, 2009. It: (i) defines the variables subject to the quantitative targets specified in the Letter of Intent (LOI); (ii) describes the methods to be used in assessing the program performance and the information requirements to ensure adequate monitoring of the targets (Section I); and (iii) provides clarifications for some of the structural conditionality under the program (Section II). As is standard under all Fund arrangements, we will consult with the Fund before modifying measures contained in this letter, or adopting new measures that would deviate from the goals of the program, and provide the Fund with the necessary information for program monitoring.

2. For the purposes of the program, the exchange rates of the Romanian Leu (RON) to the euro is set at RON $3.9852=€ 1$, to the U.S. dollar at RON $2.8342=\$ 1$, to the Japanese yen at RON $3.1419=¥ 100$, and to the pound sterling at RON $4.1169=£ 1$, the rates as shown on the National Bank of Romania's (NBR's) website as of December 31, 2008. The exchange rates to other currencies, where applicable, will also be the ones shown on the NBR's website as of December 31, 2008.

3. For the purposes of the program, the general government includes the entities as defined in the 2009 budget. These are: the central government (state budget, treasury, selffinanced state entities included in the budget, etc.), local governments, social security funds (pension, health, and unemployment), road fund company, and administration of the property fund. This definition of general government also includes any new funds, or other special budgetary and extra budgetary programs that may be created during the program period to carry out operations of a fiscal nature as defined in the IMF's Manual on Government Finance Statistics 2001. The authorities will inform IMF staff of the creation of any such new funds or programs immediately.

\section{Quantitative Performance Criteria, Indicative Ceiling, And Continuous Performance Criteria}

\section{A. Floor on the Net Foreign Assets}

\section{For program purposes, Net Foreign Assets (NFA) are defined as the NFA of the NBR minus Treasury liabilities to the International Monetary Fund.}

5. NFA of the National Bank of Romania (NBR) are defined as the euro value of gross foreign assets of the NBR (including reserve requirements of the commercial banking system held at the NBR) minus gross foreign liabilities of the NBR; and will be measured on the basis of the NBR's operational rather than accounting definitions. Non-euro denominated foreign assets and liabilities will be converted into euro at the program exchange rates. 
6. Gross foreign assets of the NBR are defined to include the NBR's holdings of SDRs, the country's reserve position at the Fund, holdings of cash, securities and deposits abroad in convertible foreign currencies. Excluded from reserve assets are: (i) gold and other precious metals; (ii) assets in nonconvertible currencies; (iii) illiquid assets; (iv) any assets that are pledged, collateralized, or otherwise encumbered, unless there is also a gross foreign liability associated with it; (v) claims on residents; and (vi) claims in foreign exchange arising from derivatives in foreign currencies vis-à-vis domestic currency (such as futures, forwards, swaps, and options).

7. Gross foreign liabilities of the NBR are defined as all foreign exchange liabilities to residents and nonresidents, including commitments to sell foreign exchange arising from derivatives (such as futures, forwards, swaps, and options), and all credit outstanding from the Fund, but excluding (i) banks' foreign currency deposits against reserve requirements; and (ii) government foreign currency deposits at the NBR. This definition is meant to bring the concept of foreign liabilities closer to the balance of payment definition, on which the targets are based.

Floor on cumulative change in NFA from the beginning of the year (in mln. euros) 1/

\begin{tabular}{|c|c|c|c|c|c|c|}
\hline & \multirow{2}{*}{$\begin{array}{c}2008 \\
\text { December }\end{array}$} & \multicolumn{4}{|c|}{2009} & \multirow{2}{*}{$\begin{array}{c}2010 \\
\text { December }\end{array}$} \\
\hline & & March & June & September & December & \\
\hline & (stock) & (actual) & (actual) & $\mathrm{PC}$ & $\mathrm{PC}$ & IT \\
\hline Cumulative change in NFA & 25,532 & $-3,468$ & $-5,118$ & $-8,720$ & $-9,000$ & -500 \\
\hline \multicolumn{7}{|l|}{ Memorandum Item: } \\
\hline Gross Foreign Assets & 26,220 & $-1,549$ & -132 & $-1,200$ & 0 & 3,000 \\
\hline
\end{tabular}

1/ $\mathrm{PC}=$ performance criterion; IT=indicative target. Data for end-month.

8. NFA targets will be adjusted upward (downward) by the surplus (shortfall) in program disbursements relative to the baseline projection. Program disbursements are defined as external disbursements from official creditors (World Bank and the EC) that are usable for the financing of the overall central government budget. The NFA targets will also be adjusted upward by the increase in commercial bank reserve requirements held with the NBR relative to end-December, 2008 ( $€ 13,038$ million), measured at program exchange rates. The SDR allocation to Romania in the third quarter of 2009 will not result in higher NFA of the NBR, as it will increase both NBR's gross foreign assets and liabilities as defined in the TMU paragraphs 6 and 7 above. 


\begin{tabular}{llllll} 
9External Program Disbursements - Baseline Projections (in mln. euros) \\
\hline & 2009 & & & $\begin{array}{l}2010 \\
\text { December }\end{array}$ \\
\cline { 2 - 5 } & March & June & September & December & \\
\hline $\begin{array}{l}\text { Cumulative flows from end- } \\
\text { December 2008 }\end{array}$ & 0 & 0 & 1,300 & 2,800 & 2,350 \\
\hline
\end{tabular}

\section{B. Consultation Mechanism on the 12-month Rate of Inflation}

9. The quarterly consultation bands for the 12-month rate of inflation in consumer prices (as measured by the headline consumer price index (CPI) published by the Romanian Statistical Institute), are specified below. Should the observed year-on-year rate of CPI inflation fall outside the outer bands specified above, the authorities will complete a consultation with the Fund on their proposed policy response before requesting further purchases under the program. In addition, the NBR will conduct discussions with the Fund staff should the observed year-on-year rate of CPI inflation fall outside the inner bands specified for the end of each quarter in the table above.

\begin{tabular}{|c|c|c|c|c|c|c|}
\hline & \multirow{2}{*}{$\begin{array}{l}2008 \\
\text { December }\end{array}$} & \multicolumn{4}{|c|}{2009} & \multirow{2}{*}{$\begin{array}{l}2010 \\
\text { December }\end{array}$} \\
\hline & & March & June & September & December & \\
\hline Outer band (upper limit) & $\ldots$ & $\ldots$ & $\ldots$ & 7.7 & 6.5 & 4.5 \\
\hline Inner band (upper limit) & $\ldots$ & $\ldots$ & $\ldots$ & 6.7 & 5.5 & 3.5 \\
\hline Center point & 6.3 & 6.7 & 5.9 & 5.7 & 4.5 & 2.5 \\
\hline Inner band (lower limit) & $\ldots$ & $\ldots$ & $\ldots$ & 4.7 & 3.5 & 1.5 \\
\hline Outer band (lower limit) & $\ldots$ & $\ldots$ & $\ldots$ & 3.7 & 2.5 & 0.5 \\
\hline
\end{tabular}

\section{Performance Criterion on General Government Balance}

10. The budget deficit will be monitored quarterly through the cash balance of the general government. The authorities will consult with IMF staff on corrective measures in the event of shortfalls in government revenue and financing.

\begin{tabular}{lc} 
Cumulative floor on general government balance & \\
\hline & (In millions of lei) \\
\hline & \\
End-March 2009 (actual) & $-8,300$ \\
End-June 2009 (actual) & $-14,456$ \\
End-September 2009 (performance criterion) & $-26,900$ \\
End-December 2009 (performance criterion) & $-36,500$ \\
\hline
\end{tabular}

11. The budget deficit will be measured from above the line using the budget execution data. The Ministry of Public Finance (MPF) will also provide monthly data to measure the 
deficit from below the line. The balance of the general government measured from below the line will include:

+(i) net external financing, excluding valuation gains and losses;

+ (ii) change in net domestic credit from the financial system, excluding valuation gains and losses from deposits denominated in foreign currency and including adjustments for;

+ (a) received EU funds not yet spent (advance payments);

+ (b) claims of the government on EU funds;

+ (c) property fund obligations not yet paid;

+ (iii) change in the stock of issued government securities, net of valuation changes;

+ (iv) net changes in other financing.

12. If the difference between the general government deficit measured from above the line and from below the line is larger than lei 200 million each quarter during 2009, and to be determined for 2010 during the second review, the Ministry of Public Finance will consult with IMF staff.

13. In the event that non-grant revenues exceed those projected under the program, the deficit target will be adjusted downward by one half of the surplus to allow for additional capital spending while reducing the deficit further. The following table shows the accumulated projected non-grant revenue for 2009, to which the actual non-grant revenue will be compared.

\begin{tabular}{lc}
$\begin{array}{l}\text { Cumulative projected revenue of general government, net of EU } \\
\text { funds }\end{array}$ & (In millions of lei) \\
\hline End-March 2009 (actual) & 37,204 \\
End-June 2009 (actual) & 75,069 \\
End-September 2009 (forecast) & 110,050 \\
End-December 2009 (forecast) & 149,518 \\
\hline
\end{tabular}

\section{Performance Criterion Limiting the Issuance of Government Guarantees to the Non-Financial Private Sector and Public Enterprises}

14. The issuance of general government guarantees to the non-financial private sector and public enterprises will be limited during the program period. 


\begin{tabular}{lc}
$\begin{array}{l}\text { Ceiling on new general government guarantees issued from end- } \\
\text { 2008 until: }\end{array}$ & (In billions of lei) \\
\hline & $\ldots$ \\
End-March 2009 (actual) & 6.0 \\
End-June 2009 (actual) & 7.7 \\
End-September 2009 (performance criterion) & 7.7 \\
End-December 2009 (performance criterion) & \\
\hline
\end{tabular}

\section{E. Performance Criterion on Non-Accumulation of Domestic Arrears by the General Government}

15. The performance criterion established on the change in domestic payments arrears of the general government contemplates no accumulation of new arrears and their elimination during the program period. In case of need, the government will take corrective measures to prevent the accumulation of new spending arrears. For the purpose of the program, arrears mean accounts payable past due date by 90 days (in line with ESA95 definitions for expenditures).

\begin{tabular}{lc}
$\begin{array}{l}\text { Cumulative change in general government arrears from the end of } \\
\text { previous year }\end{array}$ & (In billions of lei) \\
\hline & \\
December 31, 2008 (stock, actual) & 1.06 \\
End-March 2009 (actual) & 0.35 \\
End-June 2009 (actual) & 0.49 \\
End-September 2009 (performance criterion) & 0.0 \\
End-December 2009 (performance criterion) & -0.15 \\
End-December 2010 (indicative target) & -0.91 \\
\hline
\end{tabular}

\section{F. Continuous Performance Criteria on Non-Accumulation of External Debt Payments Arrears by the General Government}

16. The general government will not accumulate external debt arrears during the program period. For the purposes of this performance criterion, an external debt payment arrear will be defined as a payment by the general government, which has not been made within seven days after falling due. The performance criterion will apply on a continuous basis.

\section{G. Indicative Target on General Government Primary Spending}

17. The indicative target on primary expenditure of the general government, i.e., overall spending excluding interest payments, net of disbursements of pre-accession and postaccession EU funds, will be subject to the same adjustor as applied to the deficit target. 


\begin{tabular}{lc}
\hline $\begin{array}{l}\text { Cumulative change in general government primary expenditures, } \\
\text { net of EU funds }\end{array}$ & (In millions of lei) \\
\hline & \\
December 31, 2008 (actual) & 182,411 \\
End-March 2009 (actual) & 44,120 \\
End-June 2009 (indicative target) & 87,505 \\
\hline
\end{tabular}

\section{H. Indicative Target on General Government Current Primary Spending}

18. The indicative target on current primary expenditure of the general government is defined as spending on personnel, goods and services, subsidies, transfers to public entities, Reserve Fund, and other expenditure as classified in the monthly reporting tables:

\begin{tabular}{lc}
\hline $\begin{array}{l}\text { Cumulative change in general government current primary } \\
\text { expenditures }\end{array}$ & $\begin{array}{c}\text { (In millions of } \\
\text { lei) }\end{array}$ \\
\hline & \\
End-March 2009 (actual) & 22,149 \\
End-June 2009 (actual) & 42,849 \\
End-September 2009 (indicative target) & 63,725 \\
End-December 2009 (indicative target) & 81,015 \\
\hline
\end{tabular}

\section{Monitoring of Public Enterprises}

19. The Ministry of Public Finance, the Ministry of Labor and Social Protection, and other pertinent institutions will provide information to document that a monitoring system of public enterprises is in place by the time of the first review. During the program period, information will be provided to document that sanctions - decline in remuneration and dismissal of management according to Ordinances 37/2008 and 79/2008 - are imposed if the budgets and company targets for restructuring are not observed.

20. Following the first review, monitoring will focus on the following public enterprises: (1) C.N. Cai Ferate CFR; (2) S.N. Transport CFR Calatori; (3) CN a Huilei; (4) SC Termoelectrica; (5) C.N. de Autostrazi si Drumuri Nationale; (6) S.C. Metrorex; (7) S.N. de Transport Feroviar CFR Marfa S.A.; (8) SC Electrocentrale Bucuresti; (9) Societatea Comerciala Electrificare CFR S.A.; and (10) S.C. Administratia Nationala a Imbunatatirilor Funciare.

21. During the second review, after the monitoring system of the Ministry of Public Finance has been refined, quarterly indicative targets for 2010 will be established on the operating balance (earnings before interest and tax), net of subsidies, of the 30 largest enterprises by total expenditures (as of 2009). 


\section{J. Reporting Requirements}

22. Performance under the program will be monitored from data supplied to the IMF by the NBR and the Ministry of Finance as outlined in Table 1. The authorities will transmit promptly to the IMF staff any data revisions as well as other information necessary to monitor the arrangement with the IMF.

Table 1. Romania: Data Provision to the IMF

\begin{tabular}{|c|c|}
\hline Item & Periodicity \\
\hline
\end{tabular}

To be provided by the Ministry of Finance

Preliminary monthly data on general government accounts

Quarterly final data on general government accounts

The budget deficit of the general government using ESA95 definition

Preliminary data on below-the-line financing for the general government

Final quarterly data on below-the-line financing for the general government

Total accounts payable and arrears of the general government

Total accounts payable and arrears of the central government and social security funds

Stock of the central government external arrears Public debt and new guarantees issued by the general government

Preliminary monthly data on general government primary spending, net of EU disbursements Final quarterly data on general government primary spending, net of EU disbursements

From 2010, the operating balance, profits, arrears, and personnel expenditures of 30 largest public enterprises by total expenditures

Data on EU project grants (reimbursements and advances), capital expenditures and subsidies covered by EU advances or eligible for EU reimbursement on EU supported projects specifically agreed with the EU
Monthly, on the $25^{\text {th }}$ day of the following month

Quarterly cash data, on the $35^{\text {th }}$ day past the test date Quarterly accrual data, on the $55^{\text {th }}$ day past test date Quarterly, with a lag of three months

Monthly, with a lag of no more than 35 days past the test date

Quarterly, no later than 45 days past the test date

Quarterly, within 55 days

Monthly, within the next month

Daily, with a lag of not more than seven days

Monthly, within one month

Preliminary monthly data will be reported to the IMF staff within 25 days

Quarterly, within 35 days from the test date

Quarterly, within three months of the test date

Monthly, within three weeks of the end of each month 


\section{To be provided by the National Bank of Romania}

NFA data, by components, in both program and actual exchange rates

Weekly, each Monday succeeding the reporting week and with a 3 working day lag in the case of endquarter data

Monetary survey data in the format agreed with IMF staff

The schedule of contractual external payments of the banking sector falling due in the next four quarters, interest and amortization (for medium and long-term loans)

The schedule of contractual external payments of the corporate sector falling due in the next four quarters interest and amortization (for medium and long-term loans)

The stock of short-term external debt of banks and corporates

Balance of payments in the IMF format currently used to report

Exposure (deposits, loans, subordinated loans) of (i) foreign parent banks to their subsidiaries in Romania; (ii) IFI and (iii) other creditors to banks in Romania (by national and foreign currency).

Monthly, within 30 days of the end of the month

Monthly, 45 days after the end of each month

Monthly, 45 days after the end of each month

Monthly, 45 days after the end of each month

Monthly, 45 days after the end of each month

Monthly, 20 days after the end of each month

\section{Structural Conditionality: Specifications}

\section{A. Bank Resolution}

23. The legal amendments enacted by Parliament to the banking and winding-up laws will be drafted in consultation with the IMF and will include the following elements:

- The law will specify a clear trigger for the early and mandatory appointment of a special administrator based on a regulatory threshold.

- Supplementing its existing authority, the special administrator will be granted new authority to implement promptly a broad range of restructuring measures, which shall include purchase and assumptions, sales of assets, transfer of deposits, and write downs of capital to absorb losses.

- The law will provide authority for the appointment of the special administrator with the powers of all of the banks' decision-making bodies, including the bank's general assembly of shareholders 
- The law will carve out the application of burdensome provisions, including under the general companies law, to the extent that they are inconsistent with the prompt implementation of restructuring measures (i.e., in particular, the prompt implementation of the transfer of substantial assets and of the reduction of capital to absorb all existing losses)

- The law will provide legal protection for the special administrator's good faith actions in the performance of his duties.

- The law will provide greater legal certainty for bank resolution measures during special administration so that these measures may not be suspended or reversed by litigation (i.e., such as by means of avoidance powers under the winding-up or insolvency proceedings). It will also clarify that restructuring measures are not subject to creditors' consent.

- Initiation of winding up proceedings under the winding-up law and of liquidation proceedings under the companies law will require the NBR's prior approval.

- The law will provide seniority in insolvency to depositors' claims and the same priority ranking to the Deposit Guarantee Fund.

\section{B. Public Wage Legislation}

24. The organic public wage law ("the law") to be approved by end-October 2009 will include the following provisions and requirements for subsequent implementing legislation:

a. The law will specify annual limits to expenditure on public service pay for the period from $2010-2015$ such that the wage bill is reduced progressively to 7 per cent of GDP by the end of this period. It will specify that implementation of the new pay scheme is subject to this wage bill limit and that no pay measures may be introduced that breach these annual limits. Any increases in wages will therefore be tied to employment reductions.

b. The law will not link the public pay scale to the minimum wage.

c. The law will freeze general government wages for 2010 (except for those that earn less than RON705 per month), with increases in the reference value (to which the public pay scale is indexed) after 2010 conditioned on personnel cuts needed to reach the wage bill targets as a share of GDP.

d. The law will include the following reforms of the system of bonuses: (i) it will include a limit on bonuses as a share of the total wage bill (up to 30 percent) and an individual limit per worker consistent with the overall limit; and (ii) it will specifically prohibit the creation of new bonuses and ratify the elimination and capping (or rolling into the base wage) of old bonuses. 
e. The law will require unified control of public service pay by the Cabinet. No minister or any public service official may create any new salary, allowance or bonus payment without specific authorization by Law.

f. The law will provide for the new pay system to be benchmarked on private sector wages to ensure that public pay is broadly competitive with other pay, within affordability constraints.

g. The principles underlying the new pay and grading system will include the following:

- The new grade structure will be based primarily on occupation and job responsibilities, so as to promote equal pay for equal work. This grade structure will consist of a limited number of grades based on occupation (e.g. administration; teaching; police officers), with each grade comprising distinct job families (e.g. senior managers; professionals; qualified teachers). All public service jobs shall be classified for pay purposes in accordance with this new grade structure.

- For each grade, a Grade Pay Scale shall be established, designed to provide higher rewards for jobs with greater responsibility, and to provide incentives for suitably qualified and experienced staff to take on greater responsibility. The range of each Grade Pay Scale (i.e. the difference between the maximum and minimum pay) shall be relatively narrow (except for occupations where there are few career development opportunities, such as teachers, nurses, policemen) and movement through the Grade Pay Scale shall be based significantly less on seniority than the existing coefficient system.

h. The law will include clear provisions on how it would apply outside the central government (local governments, self-financed entities).

i. The law will require that the subsequent implementing legislation: (i) be fully costed (and judged consistent with the overall wage bill limits) before submission to parliament; (ii) be approved by end-September 2010; (iii) be implemented starting January $1^{\text {st }}, 2011$.

j. A centralized system (database of all employees, grades, and pay) will be established to administer the unified pay system, with all public sector institutions required to supply such data on request. 


\section{Statement by the IMF Staff Representative on Romania September 21, 2009}

This statement reports on economic and policy developments since the staff report was issued on September 11, 2009. The information does not alter the thrust of the staff appraisal.

\section{Economic indicators for July were mixed, but remain consistent with projected} growth for the year. They confirm an incipient recovery in industry and exports, suggest that the decline in construction, retail sales, services, imports and confidence may be bottoming out, and point to a continued deterioration in employment dynamics, earnings, and bank lending. The latter three will continue to dampen domestic demand, while the recovery in industry and exports will boost the role of external demand in spurring growth. The current account continued to improve in July, shrinking by $3 / 4$ compared to the previous year. The exchange rate has remained broadly stable in recent weeks, with only modest intervention by the NBR to deal with a temporary surge in liquidity associated with Treasury operations.

2. Inflation decelerated further in August, in line with staff expectations. Annual inflation fell from 5.1 percent in July to 5 percent in August 2009. The disinflation continues to be driven by food prices offset by a significant increase in services inflation (chart). Staff projections of a 4.3 percent annual inflation by year-end remain consistent with these developments.

3. Fiscal performance to August was broadly in line with the revised program. Preliminary data suggest that the general government deficit through August was 4.4 percent of GDP, with both revenues and spending performing broadly as expected. The authorities appear likely to meet the end-September fiscal targets, although the need to repay the 0.1 percent of GDP in arrears accumulated during the first half of the year may pose a challenge. The 2009 budget has been amended in line with the revised program, and the measures needed to achieve the targets for the year have been approved by the government, fulfilling the related prior action. Parliamentary approval of legislation

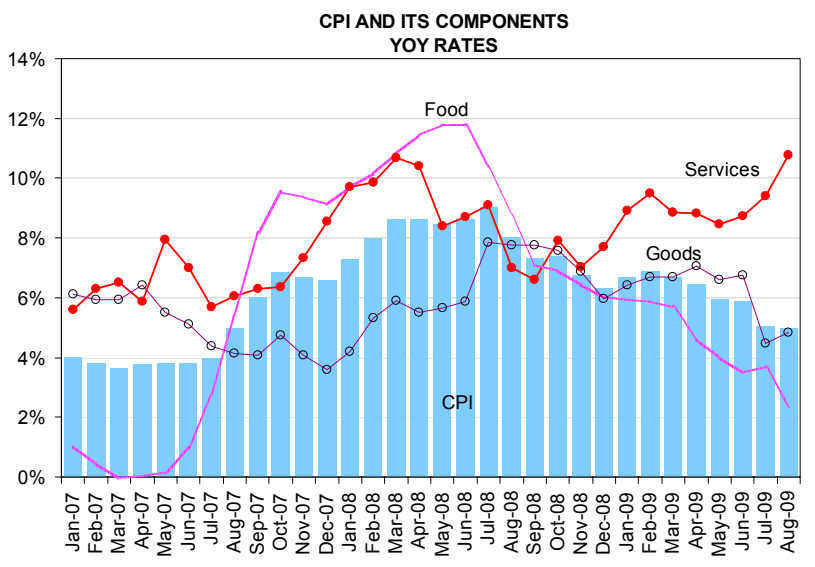
to enact the emergency measures included in the revised budget (unpaid furlough, reductions in overtime and premia, and restructuring of state agencies; $₫ 8$ of the LOI) is expected in the coming days.

4. Wage reform legislation was submitted to parliament in mid-September, and is expected to be approved shortly. As envisaged under the program, it improves on the current system by introducing a unified and simplified pay scale across the general government, reforming 
and capping bonuses, and by setting a clear mandate to reduce the wage bill to 7 percent of GDP by 2015 . However, the initial changes envisaged fall short of best practices and the legislation contains some elements that may cause significant difficulties in the future. In particular, it rigidly ties the entire pay scale to a single reference value that is envisaged to increase rapidly between 2010-15 (by 56 percent), which might require unfeasible cuts in public employment to reach the wage bill targets. Pay is not benchmarked on private sector salaries and not grouped by type of work responsibility as recommended by World Bank experts. The bonus reforms are also more timid than staff had advocated. Subsequent implementing legislation - detailing further modifications to take effect in 2011 — will be introduced by end-September 2010 and is expected to address these concerns. 
Press Release No. 09/314

International Monetary Fund

FOR IMMEDIATE RELEASE

Washington, D.C. 20431 USA

September 21, 2009

\section{IMF Completes First Review Under Stand-By Arrangement with Romania and Approves €1.85 Billion Disbursement}

The Executive Board of the International Monetary Fund (IMF) today completed the first review of Romania's economic performance under a program supported by a 24-month Stand-By Arrangement (SBA). The completion of the review enables the immediate disbursement of SDR 1.718 billion (about $€ 1.854$ billion or US $\$ 2.727$ billion), bringing total disbursements under the program to SDR 6.088 billion (about $€ 6.570$ billion or US $\$ 9.665$ billion).

The Executive Board also approved Romania's request for a waiver of non-observance of the end-June 2009 performance criterion pertaining to general government domestic arrears.

The SBA was approved on May 4, 2009 (Press Release No. 09/148) for SDR 11.443 billion (about $€ 12.348$ billion or US $\$ 18.167$ billion). The arrangement entails exceptional access to IMF resources, amounting to 1,111 percent of Romania's quota.

Following the Executive Board's discussion on Romania, Mr. John Lipsky, First Deputy Managing Director and Acting Chair, stated:

"Against the backdrop of a significant deterioration in economic activity since the approval of the Stand-by Arrangement in May, policy implementation has been strong. The deeper than expected economic downturn, however, requires a recalibration of policies so as to strike an appropriate balance between the short-term response to the crisis and the mediumterm policy objectives.

"The fiscal targets have been appropriately adjusted to partially accommodate the cyclical deterioration in revenues and avoid a negative impulse to demand, while buttressing the adjustment effort needed to reach the medium-term deficit targets. The revised program focuses on measures that would secure permanent reductions in current spending, while preserving capital and social safety net spending. However, the reductions contemplated will 
require additional reforms to strengthen controls over areas that pose the largest fiscal riskincluding expenditure commitments, pension reform, contingent liabilities, and public entities outside the central government—are crucial.

"The inflation targeting regime and flexible exchange rate policy have helped cushion the impact of the crisis while providing an appropriate anchor for monetary policy. Improved stability in financial markets and declining inflation may provide some room for further easing, but a cautious approach is warranted given the still high inflation rates and remaining vulnerabilities to external pressures. Financial policies remain appropriate to tackle the challenges posed by the crisis, and continued vigilance will be needed to respond to any signs of stress in the banking system, particularly the deterioration in asset quality to be expected as a result of the continued weak economy," Mr. Lipsky stated. 